\title{
Branch-Controlled ATRP via Sulfoxide Chemistry
}

Dongwoo Kim, ${ }^{1}$ Juhyuk Do, ${ }^{1}$ Kyungho Kim, ${ }^{1}$ Yeonji Kim, ${ }^{2}$ Hana Lee, ${ }^{2}$ Bongkuk Seo, ${ }^{3}$ Wonjoo Lee,${ }^{3}$ Heung Bae Jeon, ${ }^{2 *}$ Hong Y. Cho, ${ }^{1 *}$ and Hyun-jong Paik ${ }^{1 *}$

${ }^{1}$ Department of Polymer Science and Engineering, Pusan National University, Busan 46241, Korea

2 Department of Chemistry, Kwangwoon University, Seoul 01897, Korea

${ }^{3}$ Advanced Industrial Chemistry Research Center, Korea Research Institute of Chemical Technology,

Ulsan 44412, Korea

E-mail: hbj@kw.ac.kr; hongycho@pusan.ac.kr; hpaik@pusan.ac.kr

\section{Table of Contents}

Materials

S2

Characterizations

Experimental Procedures

NMR Analyses of SMAc

NMR Analyses of SAc

S13

NMR Analyses of sSt

S14

NMR Analysis during the Transformation of sMAc into MAc

S15

Kinetic Plot of SMAc during SE Reaction

Kinetic Plot of sAc during SE Reaction

Kinetic Plot of sSt during SE Reaction

SEC Analysis of SMAc-PMA $A_{63}$ and SAc-PMA ${ }_{63}$

Comparison of SMAc and EBiB as an initiator for SARA ATRP

SEC and ${ }^{1} \mathrm{H}$ NMR Analysis of SMAc-PMA ${ }_{299}$ and MAc-PMA 299

SEC and ${ }^{1} \mathrm{H}$ NMR Analysis of SMAc-PtBA ${ }_{157}$ and MAc-PtBA ${ }_{157}$

SEC and ${ }^{1} \mathrm{H}$ NMR Analysis of SMAc-PS 64 and MAc-PS 64

SEC and ${ }^{1} \mathrm{H}$ NMR Analysis of SAc-PMA ${ }_{87}$ and $A c-P M A_{87}$

SEC and ${ }^{1} \mathrm{H}$ NMR Analysis of sSt-PMA $A_{70}$ and St-PMA ${ }_{70}$ 


\section{Supporting Information}

\section{Materials}

Methyl acrylate (MA, TCl, 99.0\%), 2-hydroxyethyl methacrylate (TCl, 97.0\%), 2-hydroxyethyl acrylate (Sigma Aldrich, 96.0\%), and styrene (S, DAEJUNG, 99.0\%) were purified by passing through a basic alumina column before use to remove radical inhibitor. Vinylbenzyl chloride (Sigma Aldrich, $97.0 \%$ ), $\mathrm{Cu}^{0}$ wire (20 gauge, $1 \mathrm{~mm}$ diameter, Fischer), copper (II) bromide ( $\mathrm{CuBr}_{2}$, Sigma Aldrich, 98.0\%), tris[2-(dimethylamino)ethyl]amine (Me6TREN, Alfa Aesar, 99+\%), dimethyl sulfoxide (DMSO, Sigma-Aldrich, 99.7\%), anisole (Sigma Aldrich, 99.9\%), methanol (DAEJUNG, 99.5\%), thiophenol (Sigma Aldrich, 97.0\%), triethylamine (TEA, DUKSAN, 98.0\%), tetrahydrofuran (THF, DUKSAN, 99.9\%), ethyl a-bromoisobutyrate (Sigma Aldrich, 98.0\%), $\alpha$-bromoisobutyryl bromide (Sigma Aldrich, 98.0\%), acetic acid (Sigma Aldrich, 99.9\%), sodium hydroxide ( $\mathrm{NaOH}, \mathrm{DUKSAN}, 93.0 \%$ ), methylene chloride $\left(\mathrm{CH}_{2} \mathrm{Cl}_{2}\right.$, SAMCHUN, 99.5\%), ethyl acetate (EtOAc, DUKSAN, 99.5\%), hexane (DUKSAN, 95.0\%), dioxane (DUKSAN, 99.0\%), 1-octanol (JUNSEI, 98.0\%), sulfuric acid (DAEJUNG, 95.0\%), and hydrogen peroxide solution $30 \%(\mathrm{w} / \mathrm{w})$ in water $\left(\mathrm{H}_{2} \mathrm{O}_{2}\right.$, Sigma-Aldrich) were used as received.

\section{Characterizations}

Gas chromatograph (GC) was performed using HP 5890 instrument equipped with a HP101 column (methyl silicone fluid, $25 \mathrm{~m} \times 0.32 \mathrm{~mm} \times 0.30 \mu \mathrm{m})$. Size exclusion chromatography (SEC) experiment was carried out by an Agilent 1100 pump, a refractive index detector, PSS SDV precolumn $(5 \mu \mathrm{m} ; 50.0 \times 8.0 \mathrm{~mm})$, and PSS SDV columns $\left(5 \mu \mathrm{m} ; 10^{5}, 10^{3}\right.$, and $\left.10^{2} \AA ; 300.0 \times 8.0 \mathrm{~mm}\right)$ with a calibration using polystyrene standards. THF was used as an eluent at $40{ }^{\circ} \mathrm{C}$ with a flow rate of $1.0 \mathrm{~mL} \mathrm{~min}^{-1} .{ }^{1} \mathrm{H}$ Nuclear magnetic resonance $\left({ }^{1} \mathrm{H} \mathrm{NMR}\right)$ spectra were obtained on a $500 \mathrm{MHz}$ Agilent Superconducting FT-NMR spectrometer using chloroform- $d\left(\mathrm{CDCl}_{3}\right)$ as the solvent. Matrix-assisted laser desorption and ionization time-of-flight (MALDI-TOF) was performed with a Bruker Auto flex speed mass spectrometer. The instrument was operated at an accelerating potential of $20 \mathrm{kV}$ in the positive mode. Mass calibration was performed using PS standards. Trans-2-(3-(4-tert-butylphenyl)-2-methyl-2-propenylidene) malononitrile (DCTB) was used as the MALDI matrix. Sodium trifluoroacetate was used as the cationization agent. The MALDI samples were prepared with a stock solution of the matrix $\left(30 \mathrm{mg} \mathrm{mL}^{-1}\right)$, polymer analyte $\left(5 \mathrm{mg} \mathrm{mL}^{-1}\right)$, and cationization agent $\left(2 \mathrm{mg} \mathrm{mL}^{-1}\right)$ in THF. The stock solutions were mixed in a $10 / 1 / 1$ volume ratio (matrix / analyte / cation) and deposited onto a MALDI target plate. Poly(methyl acrylate) (PMA) samples were analyzed using a Bruker Ultra High Resolution electrospray ionization quadrupole time-of-flight (ESI Q-TOF) mass spectrometer. The ESI-Q-TOF mass spectrometer was performed at $4.0 \mathrm{kV}$ in a desolvation temperature of 200 ${ }^{\circ} \mathrm{C}$. The mass spectrometer was operating in the positive ion mode. Nitrogen was used as the nebulizer and drying gas. The concentration of the samples was $10 \mu \mathrm{g} \mathrm{mL}^{-1}$, and all samples were injected using a constant flow rate (3 


\section{Supporting Information}

$\mu \mathrm{L} \mathrm{min}^{-1}$ ) of sample solution. A mixture of chloroform / acetonitrile was used as a solvent. The analysis was conducted in the absence of salt or acid, however the ionization occurs from the sodium content that is naturally present in the glass or in the polymer sample. ${ }^{1}$ The ESI-Q-TOF-MS instrument was calibrated in the $\mathrm{m} / \mathrm{z}$ range 700-3,000 using a calibration standard (Tune mix solution) which is supplied from Agilent. All data were processed via Bruker Data Analysis software version 4.1.

\section{Experimental Procedures}

\section{Synthesis of 2-hydroxyethyl 2-methyl-3-(phenylthio)propanoate.}

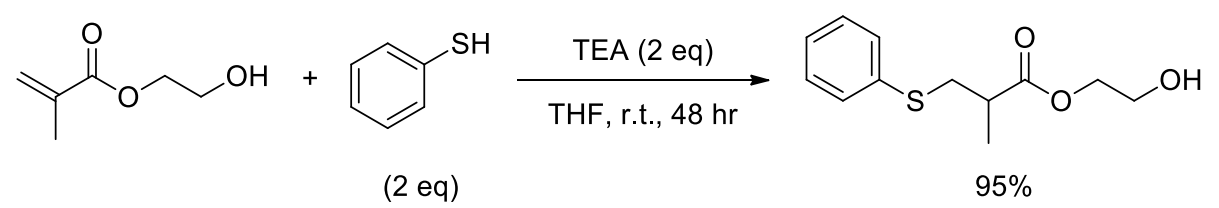

To a solution of 2-hydroxyethyl methacrylate $(4.0 \mathrm{~g}, 30.7 \mathrm{mmol})$ and thiophenol $(6.8 \mathrm{~g}, 61.5 \mathrm{mmol})$ in dry THF $(100 \mathrm{~mL})$ was added TEA $(6.2 \mathrm{~g}, 61.5 \mathrm{mmol})$ at room temperature. The resulting solution was stirred for $48 \mathrm{~h}$ at room temperature. The reaction mixture was quenched with $\mathrm{H} 2 \mathrm{O}$ and extracted with EtOAc. The organic layer was separated, dried over $\mathrm{MgSO}_{4}$ and concentrated. The residue was subjected to column chromatography with hexanes / EtOAc (2 / 1) as eluent to give the desired product $(7.0 \mathrm{~g}, 95 \%)$ as a colorless oil. ${ }^{1} \mathrm{H}$ NMR $(400 \mathrm{MHz}$, $\left.\mathrm{CDCl}_{3}\right)$ ठ 7.39-7.21 (m, 5H), 4.29-4.19 (m, 2H), 3.84 (q, J = 7.7 Hz, 2H), 3.23 (dd, J = 16.0, 8.0 Hz, 1H), 3.01 (dd, $\mathrm{J}=14.0,4.0 \mathrm{~Hz}, 1 \mathrm{H}), 2.77$ (quin, $\mathrm{J}=7.0 \mathrm{~Hz}, 1 \mathrm{H}), 2.02(\mathrm{t}, \mathrm{J}=6.4 \mathrm{~Hz}, 1 \mathrm{H}), 1.30(\mathrm{~d}, \mathrm{~J}=7.0 \mathrm{~Hz}, 3 \mathrm{H}) .{ }^{13} \mathrm{C} \mathrm{NMR}(100$ $\mathrm{MHz}, \mathrm{CDCl} 3) \delta 175.2,135.2,129.9,128.9,126.5,126.4,65.9,60.5,39.4,37.1,16.5$.

\section{Synthesis of 2-((2-bromo-2-methylpropanoyl)oxy)ethyl 2-methyl-3-(phenylthio)-propanoate.}

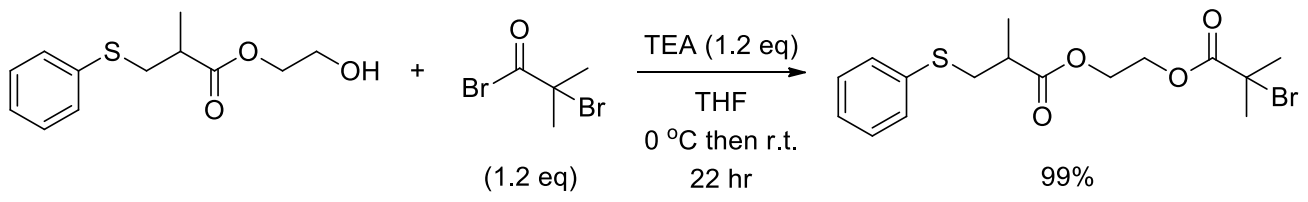

To a solution of 2-hydroxyethyl 2-methyl-3-(phenylthio)propanoate $(2.0 \mathrm{~g}, 7.1 \mathrm{mmol})$ and TEA $(0.9 \mathrm{~g}, 8.5 \mathrm{mmol})$ in dry THF $(25 \mathrm{~mL})$ at $0{ }^{\circ} \mathrm{C}$ was added dropwise $\alpha$-bromoisobutyryl bromide $(2.0 \mathrm{~g}, 8.5 \mathrm{mmol})$. The resulting solution was warmed to room temperature and allowed to stir for $22 \mathrm{~h}$. The reaction mixture was concentrated by rotary evaporator. The residue was partitioned with saturated aq. $\mathrm{Na}_{2} \mathrm{CO}_{3}$ and $\mathrm{CH}_{2} \mathrm{Cl}_{2}$. The organic layer was separated, dried over $\mathrm{MgSO}_{4}$ and concentrated. The residue was subjected to column chromatography with hexanes / EtOAc (1 / 1) as eluent to give the desired product $(3.2 \mathrm{~g}, 99 \%)$ as a colorless oil. ${ }^{1} \mathrm{H}$ NMR $\left(400 \mathrm{MHz}, \mathrm{CDCl}_{3}\right) \delta 7.38-7.36$ (m, $2 \mathrm{H}), 7.32-7.28(\mathrm{~m}, 2 \mathrm{H}), 7.24-7.19(\mathrm{~m}, 1 \mathrm{H}), 4.40-4.31(\mathrm{~m}, 4 \mathrm{H}), 3.28(\mathrm{dd}, \mathrm{J}=13.4,7.3 \mathrm{~Hz}, 1 \mathrm{H}), 2.94(\mathrm{dd}, \mathrm{J}=$ 


\section{Supporting Information}

13.4, $6.8 \mathrm{~Hz}, 1 \mathrm{H}), 2.73(\mathrm{sex}, \mathrm{J}=7.0 \mathrm{~Hz}, 1 \mathrm{H}), 1.93(\mathrm{~s}, 6 \mathrm{H}), 1.28(\mathrm{~d}, \mathrm{~J}=6.9 \mathrm{~Hz}, 3 \mathrm{H}) .{ }^{13} \mathrm{C} \mathrm{NMR}\left(100 \mathrm{MHz}, \mathrm{CDCl}_{3}\right) \delta$ $174.4,171.2,135.4,129.8,128.8,126.3,63.3,61.7,55.24,55.19,39.3,36.8,30.3,16.4$.

\section{Synthesis of 2-((2-bromo-2-methylpropanoyl)oxy)ethyl 2-methyl-3-(phenylsulfinyl)-propanoate (sMAc).}

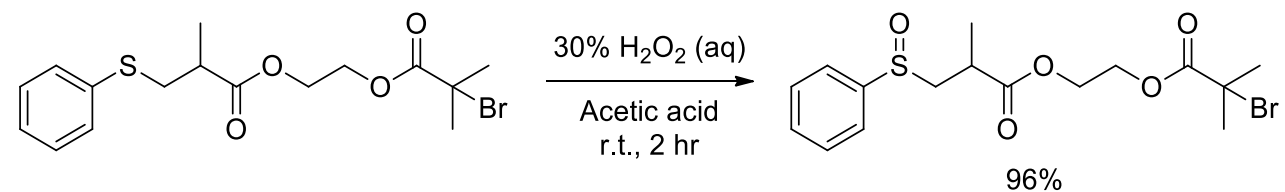

To a solution of 2-((2-bromo-2-methylpropanoyl)oxy)ethyl 2-methyl-3-(phenylthio)propanoate $(2.0 \mathrm{~g}, 5.1 \mathrm{mmol})$ in acetic acid $(19 \mathrm{~mL})$ was added dropwise $30 \%$ aq. $\mathrm{H}_{2} \mathrm{O}_{2}$ solution $(2.3 \mathrm{~mL})$ at room temperature. After stirring for $2 \mathrm{~h}$ at room temperature, the resulting solution was cooled to $0{ }^{\circ} \mathrm{C}$ and aq. $4 \mathrm{M} \mathrm{NaOH}$ was added to the solution until it becomes to $\mathrm{pH}$ 10. Then, the reaction mixture was extracted with $\mathrm{CH}_{2} \mathrm{Cl}_{2}$. The organic layer was separated, dried over $\mathrm{MgSO}_{4}$, and concentrated. The residue was subjected to column chromatography with hexanes / EtOAc (1 / 1) as eluent to give the desired product $(2.1 \mathrm{~g}, 96 \%)$ as a colorless oil. ${ }^{1} \mathrm{H}$ NMR $\left(400 \mathrm{MHz}, \mathrm{CDCl}_{3}\right) \delta 7.68-7.64$ (m, 2H), 7.57-7.50 (m, 3H), 4.49-4.23 (m, 4H), 3.29-3.22 (m, 1H), 3.18-3.04 (m, 1H), 2.79-2.73 (m, 1H), $1.95(\mathrm{~s}$, 3H), $1.90(\mathrm{~s}, 3 \mathrm{H}), 1.44(\mathrm{~d}, \mathrm{~J}=8.0 \mathrm{~Hz}, 1.5 \mathrm{H}), 1.32(\mathrm{~d}, \mathrm{~J}=8.0 \mathrm{~Hz}, 1.5 \mathrm{H}) .{ }^{13} \mathrm{C}$ NMR (100 MHz, CDCl3) ठ 173.8, 173.6, $171.25,171.20,143.8,143.2,131.08,130.98,129.18,129.16,123.8,123.6,63.2,63.1,62.1,62.0,60.6,59.9,55.2$, 55.1, 34.2, 33.7, 30.33, 30.29, 17.6, 16.4. HRMS (ESI Q-TOF) Calcd for $\mathrm{C}_{16} \mathrm{H}_{21} \mathrm{BrO}_{5} \mathrm{SNa}[\mathrm{M}+\mathrm{Na}]+:$ : 427.0191, 429.0170. Found: 427.0190, 429.0171.

\section{Synthesis of 2-Hydroxyethyl 3-(phenylthio)propanoate.}

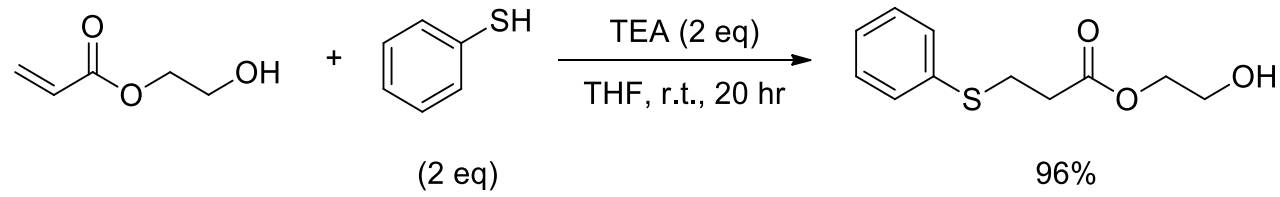

To a solution of 2-hydroxyethyl acrylate $(5.0 \mathrm{~g}, 43.1 \mathrm{mmol})$ and thiophenol $(9.5 \mathrm{~g}, 86.1 \mathrm{mmol})$ in dry THF (100 $\mathrm{mL}$ ) was added TEA $(8.7 \mathrm{~g}, 86.1 \mathrm{mmol})$ at room temperature. The resulting solution was stirred for $20 \mathrm{~h}$ at room temperature. The reaction mixture was quenched with $\mathrm{H}_{2} \mathrm{O}$ and extracted with EtOAc. The organic layer was separated, dried over $\mathrm{MgSO}_{4}$ and concentrated. The residue was subjected to column chromatography with hexanes / EtOAc (2 / 1) as eluent to give the desired product $(9.4 \mathrm{~g}, 96 \%)$ as a colorless oil. ${ }^{1} \mathrm{H}$ NMR $(400 \mathrm{MHz}$, $\left.\mathrm{CDCl}_{3}\right) \delta$ 7.43-7.21 (m, 5H), $4.24(\mathrm{t}, \mathrm{J}=4.8 \mathrm{~Hz}, 2 \mathrm{H}), 3.84(\mathrm{t}, \mathrm{J}=3.7 \mathrm{~Hz}, 2 \mathrm{H}), 3.19(\mathrm{t}, \mathrm{J}=7.3 \mathrm{~Hz}, 2 \mathrm{H}), 2.69(\mathrm{t}, \mathrm{J}=$ $7.4 \mathrm{~Hz}, 2 \mathrm{H}), 1.95(\mathrm{t}, \mathrm{J}=5.0 \mathrm{~Hz}, 1 \mathrm{H}) .{ }^{13} \mathrm{C}$ NMR $(100 \mathrm{MHz}, \mathrm{CDCl} 3) \delta 171.9,134.7,129.9,128.8,126.5,66.0,60.5$, $34.0,28.8$. 


\section{Supporting Information}

Synthesis of 2-((3-(phenylthio)propanoyl)oxy)ethyl 2-bromo-2-methylpropanoate.

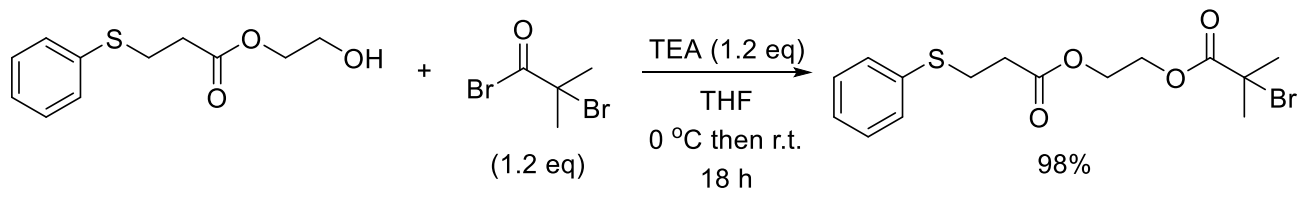

To a solution of 2-hydroxyethyl 3-(phenylthio)propanoate $(2.0 \mathrm{~g}, 8.8 \mathrm{mmol})$ and TEA $(1.1 \mathrm{~g}, 10.6 \mathrm{mmol})$ in dry THF $(25 \mathrm{~mL})$ at $0{ }^{\circ} \mathrm{C}$ was added dropwise a-bromoisobutyryl bromide $(2.4 \mathrm{~g}, 10.6 \mathrm{mmol})$. The resulting solution was warmed to room temperature and allowed to stir for $18 \mathrm{~h}$. The reaction mixture was concentrated by rotary evaporator. The residue was partitioned with saturated aq. $\mathrm{Na}_{2} \mathrm{CO}_{3}$ and $\mathrm{CH}_{2} \mathrm{Cl}_{2}$. The organic layer was separated, dried over $\mathrm{MgSO}_{4}$ and concentrated. The residue was subjected to column chromatography with hexanes / EtOAc (4 / 1) as eluent to give the desired product $(3.3 \mathrm{~g}, 98 \%)$ as a colorless oil. ${ }^{1} \mathrm{H}$ NMR $\left(400 \mathrm{MHz}, \mathrm{CDCl}_{3}\right) \delta 7.39-7.36$ $(\mathrm{m}, 2 \mathrm{H}), 7.33-7.29(\mathrm{~m}, 2 \mathrm{H}), 7.24-7.21(\mathrm{~m}, 1 \mathrm{H}), 4.40-4.34(\mathrm{~m}, 4 \mathrm{H}), 3.18(\mathrm{t}, \mathrm{J}=7.4 \mathrm{~Hz}, 2 \mathrm{H}), 2.66(\mathrm{t}, \mathrm{J}=7.3 \mathrm{~Hz}, 2 \mathrm{H})$, $1.93(\mathrm{~s}, 6 \mathrm{H}) .{ }^{13} \mathrm{C} \mathrm{NMR}\left(100 \mathrm{MHz}, \mathrm{CDCl}_{3}\right) \delta 171.05,171.02,134.8,129.8,128.8,126.3,63.2,61.6,55.2,33.9,30.4$, 28.6.

Synthesis of 2-((3-(phenylsulfinyl)propanoyl)oxy)ethyl 2-bromo-2-methylpropanoate (sAc).<smiles>CC(C)(Br)C(=O)OCCOC(=O)CCS(=O)c1ccccc1</smiles>

To a solution of 2-((3-(phenylthio)propanoyl)oxy)ethyl 2-bromo-2-methylpropanoate $(2.0 \mathrm{~g}, 5.3 \mathrm{mmol})$ in acetic acid $(16 \mathrm{~mL})$ was added dropwise $30 \%$ aq. $\mathrm{H}_{2} \mathrm{O}_{2}$ solution $(2.4 \mathrm{~mL})$ at room temperature. After stirring for $2 \mathrm{~h}$ at room temperature, the resulting solution was cooled to $0^{\circ} \mathrm{C}$ and aq. $4 \mathrm{M} \mathrm{NaOH}$ was added to the solution until it becomes to $\mathrm{pH}$ 10. Then, the reaction mixture was extracted with $\mathrm{CH}_{2} \mathrm{Cl}_{2}$. The organic layer was separated, dried over $\mathrm{MgSO}_{4}$ and concentrated. The residue was subjected to column chromatography with hexanes / EtOAc (1/ 1) as eluent to give the desired product $(2.0 \mathrm{~g}, 95 \%)$ as a colorless oil. ${ }^{1} \mathrm{H} \mathrm{NMR}\left(400 \mathrm{MHz}, \mathrm{CDCl}_{3}\right) \delta 7.64-7.62(\mathrm{~m}$, 2H), 7.57-7.52 (m, 3H), 4.38-4.33 (m, 4H), 3.29-3.22 (m, 1H), 3.00-2.84 (m, 2H), 2.62-2.56 (m, 1H), $1.93(\mathrm{~s}, 6 \mathrm{H})$. ${ }^{13} \mathrm{C}$ NMR $\left(100 \mathrm{MHz}, \mathrm{CDCl}_{3}\right) \delta 171.0,170.5,142.5,130.9,129.0,123.6,63.0,61.9,55.2,50.49,50.46,30.3,25.6$. HRMS (ESI Q-TOF) Calcd for $\mathrm{C}_{15} \mathrm{H}_{19} \mathrm{BrO}_{5} \mathrm{SNa}[\mathrm{M}+\mathrm{Na}]+:$ 413.0034, 415.0014. Found: 413.0034, 415.0015.

\section{Synthesis of (4-(chloromethyl)phenethyl)(phenyl)sulfane.}

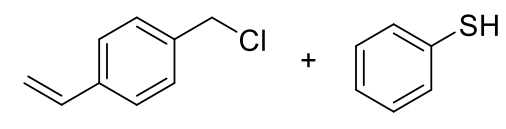

$(1.2 \mathrm{eq})$

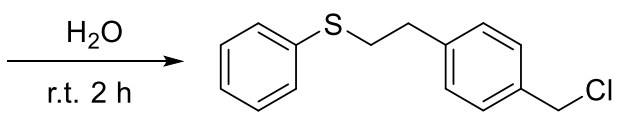

$85 \%$ 


\section{Supporting Information}

To a solution of vinylbenzyl chloride $(3.0 \mathrm{~g}, 19.7 \mathrm{mmol})$ in $\mathrm{H}_{2} \mathrm{O}(50 \mathrm{~mL})$ was added thiophenol $(2.6 \mathrm{~g}, 23.4$ $\mathrm{mmol}$ ) at room temperature. The resulting solution was stirred for $2 \mathrm{~h}$ at room temperature. The reaction mixture was extracted with $\mathrm{CH}_{2} \mathrm{Cl}_{2}$. The organic layer was separated, washed with $10 \%$ aq. $\mathrm{NaOH}$ and $\mathrm{H}_{2} \mathrm{O}$, dried over $\mathrm{MgSO}_{4}$ and concentrated to give the desired product $(4.4 \mathrm{~g}, 85 \%)$ as a colorless oil. The residue was used for next step without any further purification. ${ }^{1} \mathrm{H}$ NMR $\left(400 \mathrm{MHz}, \mathrm{CDCl}_{3}\right) \delta$ 7.38-7.29 (m, 6H), 7.23-7.19 (m, 3H), $4.59(\mathrm{~s}$, 2H), $3.17(\mathrm{t}, \mathrm{J}=7.8 \mathrm{~Hz}, 2 \mathrm{H}), 2.93(\mathrm{t}, \mathrm{J}=8.0 \mathrm{~Hz}, 2 \mathrm{H}) .{ }^{13} \mathrm{C} \mathrm{NMR}\left(100 \mathrm{MHz}, \mathrm{CDCl}_{3}\right) \delta$ 140.5, 136.1, 135.6, 129.2, 128.94, 128.89, 128.8, 126.1, 35.2, 34.9.

Synthesis of 2-((4-(2-(phenylthio)ethyl)benzyl)oxy)ethanol.
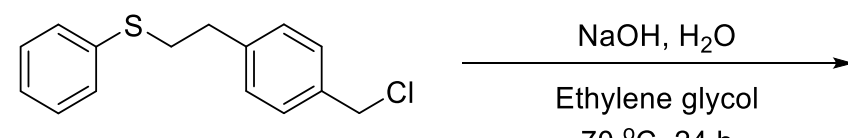

$70{ }^{\circ} \mathrm{C}, 24 \mathrm{~h}$

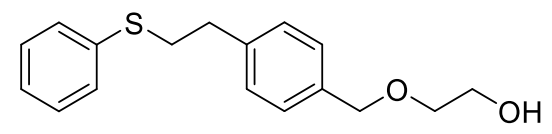

$64 \%$

A solution of 4-(chloromethyl)phenethyl)(phenyl)sulfane $(4.0 \mathrm{~g}, 15.2 \mathrm{mmol})$ and $\mathrm{NaOH}(0.6 \mathrm{~g}, 15.2 \mathrm{mmol})$ in $\mathrm{H}_{2} \mathrm{O}(0.3 \mathrm{~mL})$ and ethylene glycol $(22 \mathrm{~mL})$ was stirred at $70 \stackrel{\circ}{\circ} \mathrm{C}$ for $24 \mathrm{~h}$. The reaction mixture was cooled to room temperature, quenched with $\mathrm{H}_{2} \mathrm{O}$, and extracted with EtOAc. The organic layer was separated, dried over $\mathrm{MgSO}_{4}$ and concentrated. The residue was subjected to column chromatography with $\mathrm{CH}_{2} \mathrm{Cl}_{2} / \mathrm{EtOAc}(7 / 1)$ as eluent to give the desired product $(4.4 \mathrm{~g}, 64 \%)$ as a colorless oil. ${ }^{1} \mathrm{H}$ NMR $\left(400 \mathrm{MHz}, \mathrm{CDCl}_{3}\right)$ ס 7.39-7.36 (m, 2H), 7.33-7.29 (m, 4H), 7.23-7.19 (m, 3H), $4.55(\mathrm{~s}, 2 \mathrm{H}), 3.77(\mathrm{q}, \mathrm{J}=4.9 \mathrm{~Hz}, 2 \mathrm{H}) 3.60(\mathrm{t}, \mathrm{J}=2.5 \mathrm{~Hz}, 2 \mathrm{H}), 3.18(\mathrm{t}, \mathrm{J}=8.0 \mathrm{~Hz}, 2 \mathrm{H})$, $2.94(\mathrm{t}, \mathrm{J}=8.0 \mathrm{~Hz}, 2 \mathrm{H}), 2.22(\mathrm{~s}, 1 \mathrm{H}) .{ }^{13} \mathrm{C} \mathrm{NMR}\left(100 \mathrm{MHz}, \mathrm{CDCl}_{3}\right) \delta 139.8,136.2,136.1,129.2,128.9,128.6,128.0$, $126.0,73.0,71.3,61.8,35.2,35.0$.

\section{Synthesis of 2-((4-2-(phenylthio)ethyl)benzyl)oxy)ethyl 2-bromo-2-methylpropanoate.}

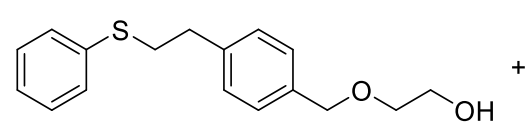<smiles>CC(C)(Br)C(=O)Br</smiles>

$(1.2 \mathrm{eq})$

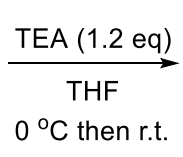

$18 \mathrm{~h}$

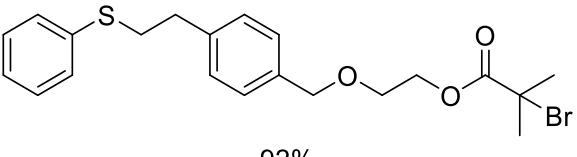

$92 \%$

To a solution of 2-((4-2-(phenylthio)ethyl)benzyl)oxy)ethanol $(2.0 \mathrm{~g}, 6.9 \mathrm{mmol})$ and TEA $(0.8 \mathrm{~g}, 8.3 \mathrm{mmol})$ in dry THF $(20 \mathrm{~mL})$ at $0{ }^{\circ} \mathrm{C}$ was added dropwise $\alpha$-bromoisobutyryl bromide $(1.9 \mathrm{~g}, 8.3 \mathrm{mmol})$. The resulting solution was warmed to room temperature and allowed to stir for $18 \mathrm{~h}$. The reaction mixture was concentrated by rotary evaporator. The residue was partitioned with saturated aq. $\mathrm{Na}_{2} \mathrm{CO}_{3}$ and $\mathrm{CH}_{2} \mathrm{Cl}_{2}$. The organic layer was separated, dried over $\mathrm{MgSO}_{4}$ and concentrated. The residue was subjected to column chromatography with hexanes / EtOAc (3 / 1) as eluent to give the desired product $(2.8 \mathrm{~g}, 92 \%)$ as a colorless oil. ${ }^{1} \mathrm{H}$ NMR $\left(400 \mathrm{MHz}, \mathrm{CDCl}_{3}\right) \delta 7.37-7.35$ (m, 2H), 7.33-7.28 (m, 4H), 7.22-7.18 (m, 3H), $4.56(\mathrm{~s}, 2 \mathrm{H}), 4.37(\mathrm{t}, \mathrm{J}=4.8 \mathrm{~Hz}, 2 \mathrm{H}), 3.72(\mathrm{t}, \mathrm{J}=4.8 \mathrm{~Hz}, 2 \mathrm{H}), 3.14-$ 


\section{Supporting Information}

$3.18(\mathrm{~m}, 2 \mathrm{H}), 2.95-2.91(\mathrm{~m}, 2 \mathrm{H}), 1.96(\mathrm{~s}, 6 \mathrm{H}) .{ }^{13} \mathrm{C} \mathrm{NMR}\left(100 \mathrm{MHz}, \mathrm{CDCl}_{3}\right) \delta$ 171.5, 139.6, 136.2, 136.0, 129.0, $128.8,128.5,127.8,125.8,72.8,67.4,65.0,55.6,35.2,34.9,30.6$.

Synthesis of 2-((4-2-(Phenylsulfinyl)ethyl)benzyl)oxy)ethyl 2-bromo-2-methylpropanoate (sSt).

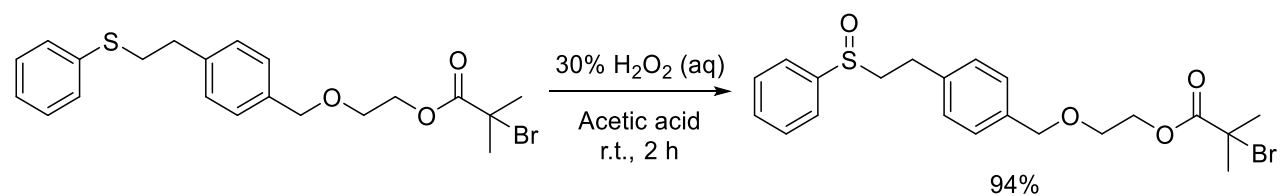

To a solution of 2-((4-2-(Phenylthio)ethyl)benzyl)oxy)ethyl 2-bromo-2-methylpropanoate $(2.0 \mathrm{~g}, 4.6 \mathrm{mmol})$ in acetic acid $(14 \mathrm{~mL})$ was added dropwise $30 \%$ aq. $\mathrm{H}_{2} \mathrm{O}_{2}$ solution $(2.1 \mathrm{~mL})$ at room temperature. After stirring for $2 \mathrm{~h}$ at room temperature, the resulting solution was cooled to $0{ }^{\circ} \mathrm{C}$ and aq. $4 \mathrm{M} \mathrm{NaOH}$ was added to the solution until it becomes to $\mathrm{pH}$ 10. Then, the reaction mixture was extracted with $\mathrm{CH}_{2} \mathrm{Cl}_{2}$. The organic layer was separated, dried over $\mathrm{MgSO}_{4}$ and concentrated. The residue was subjected to column chromatography with hexanes / EtOAc (1/ 2) as eluent to give the desired product $(1.9 \mathrm{~g}, 94 \%)$ as a colorless oil. ${ }^{1} \mathrm{H}$ NMR $\left(400 \mathrm{MHz}, \mathrm{CDCl}_{3}\right) \delta 7.65-7.63(\mathrm{~m}$, 2H), 7.56-7.48 (m, 3H), $7.28(\mathrm{~d}, \mathrm{~J}=8.4 \mathrm{~Hz}, 2 \mathrm{H}), 7.17(\mathrm{~d}, \mathrm{~J}=7.8 \mathrm{~Hz}, 2 \mathrm{H}), 4.54(\mathrm{~s}, 1 \mathrm{H}), 4.35(\mathrm{t}, \mathrm{J}=4.8 \mathrm{~Hz}, 2 \mathrm{H}), 3.71$ $(\mathrm{t}, \mathrm{J}=4.8 \mathrm{~Hz}, 2 \mathrm{H}), 3.14-2.92(\mathrm{~m}, 4 \mathrm{H}), 1.95(\mathrm{~s}, 6 \mathrm{H}) .{ }^{13} \mathrm{C} \mathrm{NMR}\left(100 \mathrm{MHz}, \mathrm{CDCl}_{3}\right) \delta$ 171.5, 143.5, 138.2, 136.3, 130.9, 129.1, 128.5, 128.0, 123.8, 72.7, 67.5, 65.0, 58.1, 55.6, 30.6, 27.7. HRMS (ESI Q-TOF) Calcd for $\mathrm{C}_{21} \mathrm{H}_{25} \mathrm{BrO}_{4} \mathrm{SNa}$ $[\mathrm{M}+\mathrm{Na}]+:$ 475.0555, 477.0534. Found: 475.0552, 477.0534 .

\section{Transformation of the sulfoxide-protected haloalkanes into ATRP inimers}

A solution of the protected haloalkanes in anisole $(50 \mathrm{mM})$ was added into a Schlenk flask sealed with rubber septa. The flask was placed in an oil bath at the indicated temperature under stirring. The conversion of the protected haloalkanes was measured at timed intervals and withdrawn samples were diluted with $\mathrm{CDCl}_{3}$ for ${ }^{1} \mathrm{H}$ NMR spectroscopy.

\section{Synthesis of SMAc-PMA 63 by SARA ATRP.}

Into a $10 \mathrm{~mL}$ of Schlenk flask, $\mathrm{CuBr}_{2}(5.5 \mathrm{mg}, 24.7 \mu \mathrm{mol})$ and $\mathrm{Cu}^{0}$ wire $(\mathrm{I} \times \mathrm{d}=3 \mathrm{~cm} \times 1 \mathrm{~mm})$ was added. After sealed with rubber septa, the flask was evacuated and backfilled with $\mathrm{N}_{2}$ gas three times. A degassed mixture of MA (4.47 mL, $49.3 \mathrm{mmol})$, sMAc (200 mg, $0.493 \mathrm{mmol})$, Me 6 TREN (20.5 mg, $88.8 \mu \mathrm{mol})$, and DMSO (2.20 mL) were added to the flask via $\mathrm{N}_{2}$-purged syringes. The reaction mixture was placed in an oil bath at $25{ }^{\circ} \mathrm{C}$ under stirring for $30 \mathrm{~min}$. The monomer conversion was measured using ${ }^{1} \mathrm{H}$ NMR spectroscopy $\left(\mathrm{CDCl}_{3}, 25^{\circ} \mathrm{C}\right)$. After the reaction, the mixture was diluted with THF and passed through basic alumina to remove catalyst. Resulting solution was precipitated twice in $200 \mathrm{~mL}$ cold methanol under stirring. The polymer was isolated as a solution after 


\section{Supporting Information}

centrifugation at $-4 \stackrel{\circ}{\circ}$ and dried by freeze drying to prevent the sulfoxide elimination. The number average molecular weight $\left(M_{\mathrm{n}, \mathrm{SEC}}\right)$ and the molecular weight distribution $\left(\Theta=M_{\mathrm{w}} / M_{\mathrm{n}}\right)$ measured using THF eluted SEC was found to be $5.8 \mathrm{kDa}$ and 1.05 , respectively.

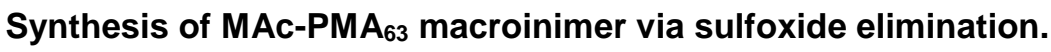

Into a $100 \mathrm{~mL}$ of flask, sMAc-PMA $63(1.0 \mathrm{~g})$ and anisole $(50 \mathrm{~mL})$ was added. The reaction mixture was stirred at $110{ }^{\circ} \mathrm{C}$ for $3 \mathrm{~h}$. The solvent was removed by freeze drying. The product was dissolved in THF $(5 \mathrm{~mL})$ and precipitated twice in $200 \mathrm{~mL}$ cold methanol under stirring. The polymer was isolated as a solution after centrifugation at $-4 \stackrel{\circ}{\circ}$ and dried by freeze drying to prevent the coupling side reaction of vinyl group. $M_{\mathrm{n}, \mathrm{SEC}}$ and $\oplus$ was found to be $5.8 \mathrm{kDa}$ and 1.05 , respectively.

\section{Synthesis of SMAc-PMA 299 by SARA ATRP.}

Into a $30 \mathrm{~mL}$ of Schlenk flask, $\mathrm{CuBr}_{2}(2.8 \mathrm{mg}, 12.3 \mu \mathrm{mol}), \mathrm{Cu}^{0}$ wire $(\mathrm{I} \times \mathrm{d}=3 \mathrm{~cm} \times 1 \mathrm{~mm})$ was added. After sealed with rubber septa, the flask was evacuated and backfilled with $\mathrm{N}_{2}$ gas three times. A degassed mixture of MA (11.2 mL, $123 \mathrm{mmol})$, sMAc (100 mg, $0.247 \mathrm{mmol}$ ), Me 6 TREN (10.2 mg, 44.4 umol), and DMSO (5.5 mL) were added to the flask via $\mathrm{N}_{2}$-purged syringes. The reaction mixture was placed in an oil bath at $25{ }^{\circ} \mathrm{C}$ under stirring for $2 \mathrm{~h}$. The monomer conversion was obtained using ${ }^{1} \mathrm{H}$ NMR spectroscopy $\left(\mathrm{CDCl}_{3}, 25^{\circ} \mathrm{C}\right)$. After the reaction, the mixture was dissolved in THF, passed through basic alumina to remove catalyst, and precipitated twice in $300 \mathrm{~mL}$ of cold methanol under stirring. The polymer was isolated as a solution after centrifugation at $-4 \stackrel{\circ}{\mathrm{C}}$ and dried by freeze drying to prevent the sulfoxide elimination. $M_{\mathrm{n}, \mathrm{SEC}}$ and $\Xi$ was found to be $26.1 \mathrm{kDa}$ and 1.04 , respectively.

\section{Synthesis of MAc-PMA299 macroinimer via sulfoxide elimination.}

Into a $100 \mathrm{~mL}$ of flask, sMAc-PMA $299(1.0 \mathrm{~g})$ and anisole $(50 \mathrm{~mL})$ was added. The mixture was stirred at 110 ${ }^{\circ} \mathrm{C}$ for $3 \mathrm{~h}$. The solvent was removed by freeze drying. The product was dissolved in THF (5 mL) and precipitated twice in $100 \mathrm{~mL}$ of cold methanol under stirring. The polymer was isolated as a solution after centrifugation at -4 ${ }^{\circ} \mathrm{C}$ and dried by freeze drying to prevent the coupling side reaction of vinyl group. $M_{n, S E C}$ and $\Xi$ was found to be $26.1 \mathrm{kDa}$ and 1.04 , respectively.

\section{Synthesis of SMAc-PtBA 157 by SARA ATRP.}

Into a $15 \mathrm{~mL}$ of Schlenk flask, $\mathrm{CuBr}_{2}(1.1 \mathrm{mg} 4.93 \mu \mathrm{mol}), \mathrm{Cu}^{0}$ wire $(\mathrm{I} \times \mathrm{d}=3 \mathrm{~cm} \times 1 \mathrm{~mm})$ was added. After sealed with rubber septa, the flask was evacuated and backfilled with $\mathrm{N}_{2}$ gas three times. A degassed mixture of tBA (4.32 mL, $29.6 \mathrm{mmol})$, sMAc (40 mg, $98.7 \mu \mathrm{mol})$, Me 6 TREN (4.1 mg, $17.8 \mu \mathrm{mol})$, and DMF (2.16 mL) were 


\section{Supporting Information}

added to the flask via $\mathrm{N}_{2}$-purged syringes. The flask was placed in an oil bath at $25{ }^{\circ} \mathrm{C}$ under stirring for $4 \mathrm{~h}$. The monomer conversion was obtained using ${ }^{1} \mathrm{H}$ NMR spectroscopy $\left(\mathrm{CDCl}_{3}, 25^{\circ} \mathrm{C}\right)$. After the reaction, the mixture was dissolved in THF, passed through basic alumina to remove catalyst, and precipitated twice in $50 \mathrm{~mL}$ of cold methanol under stirring. The polymer was isolated as a solution after centrifugation at $-4{ }^{\circ} \mathrm{C}$ and dried by freeze drying to prevent the sulfoxide elimination. $M_{\mathrm{n}, \mathrm{SEC}}$ and $\Theta$ was found to be $20.7 \mathrm{kDa}$ and 1.05 , respectively.

\section{Synthesis of MAc-PtBA 157 macroinimer via sulfoxide elimination.}

Into a $30 \mathrm{~mL}$ of Schlenk flask, sMAc-PtBA $157(200 \mathrm{mg})$ and anisole $(10 \mathrm{~mL})$ was added. The reaction mixture was stirred at $110^{\circ} \mathrm{C}$ for $3 \mathrm{~h}$. The solvent was removed by freeze drying. The product was dissolved in THF $(1 \mathrm{~mL})$ and precipitated twice in $30 \mathrm{~mL}$ of cold methanol under stirring. The polymer was isolated as a solution after centrifugation at $-4 \stackrel{\circ}{\circ} \mathrm{C}$ and dried by freeze drying prevent the coupling side reaction of vinyl group. $M_{\mathrm{n}, \mathrm{SEC}}$ and $\oslash$ was found to be $20.7 \mathrm{kDa}$ and 1.05 , respectively.

\section{Synthesis of sMAc-PS 64 by SARA ATRP.}

Into a $10 \mathrm{~mL}$ of Schlenk flask, $\mathrm{CuBr}_{2}(1.1 \mathrm{mg} 4.93 \mu \mathrm{mol}), \mathrm{Cu}^{0}$ wire $(\mathrm{I} \times \mathrm{d}=3 \mathrm{~cm} \times 1 \mathrm{~mm})$ was added. After sealed with rubber septa, the flask was evacuated and backfilled with $\mathrm{N}_{2}$ gas three times. A degassed mixture of $\mathrm{S}(3.40 \mathrm{~mL}, 29.6 \mathrm{mmol}), \mathrm{sMAc}(40 \mathrm{mg}, 98.7 \mu \mathrm{mol})$, Me6TREN (4.1 mg, $17.8 \mu \mathrm{mol})$, and DMF (0.38 mL) were added to the flask via $\mathrm{N}_{2}$-purged syringes. The reaction mixture was placed in an oil bath at $30{ }^{\circ} \mathrm{C}$ under stirring for $9 \mathrm{~h}$. The monomer conversion was obtained using ${ }^{1} \mathrm{H}$ NMR spectroscopy $\left(\mathrm{CDCl}_{3}, 25^{\circ} \mathrm{C}\right)$. After the reaction, the mixture was dissolved in THF, passed through basic alumina to remove catalyst, and precipitated twice in $30 \mathrm{~mL}$ of cold methanol under stirring. The polymer was isolated as a solution after centrifugation at $-4 \stackrel{\circ}{C}$ and dried by freeze drying to prevent the sulfoxide elimination. $M_{\mathrm{n}, \mathrm{SEC}}$ and $\boxminus$ was found to be $7.1 \mathrm{kDa}$ and 1.07 , respectively.

\section{Synthesis of MAc-PS 64 macroinimer via sulfoxide elimination.}

Into a $30 \mathrm{~mL}$ of Schlenk flask, sMAc-PS $64(200 \mathrm{mg})$ and anisole $(10 \mathrm{~mL})$ was added. The reaction mixture was stirred at $110^{\circ} \mathrm{C}$ for $3 \mathrm{~h}$. The solvent was removed by freeze drying. The product was dissolved in THF (1 mL) and precipitated twice in $30 \mathrm{~mL}$ of cold methanol under stirring. The polymer was isolated as a solution after centrifugation at $-4 \stackrel{\circ}{\circ} \mathrm{C}$ and dried by freeze drying to prevent the coupling side reaction of vinyl group. $M_{\mathrm{n}, \mathrm{SEC}}$ and $\oplus$ was found to be $6.9 \mathrm{kDa}$ and 1.08 , respectively.

\section{Synthesis of SAc-PMA ${ }_{87}$ by SARA ATRP.}




\section{Supporting Information}

Into a $10 \mathrm{~mL}$ of Schlenk flask, $\mathrm{CuBr}_{2}(5.7 \mathrm{mg}, 25.6 \mu \mathrm{mol}), \mathrm{Cu}^{0}$ wire $(\mathrm{I} \times \mathrm{d}=3 \mathrm{~cm} \times 1 \mathrm{~mm})$ was added. After sealed with rubber septa, the flask was evacuated and backfilled with $\mathrm{N}_{2}$ gas three times. A degassed mixture of MA (4.63 mL, $51.1 \mathrm{mmol}), \mathrm{sAc}(200 \mathrm{mg}, 0.511 \mathrm{mmol})$, Me 6 TREN (21.2 mg, $92.0 \mu \mathrm{mol})$, and DMSO (2.28 mL) were added to the flask via $\mathrm{N}_{2}$-purged syringes. The reaction mixture was placed in an oil bath at $25{ }^{\circ} \mathrm{C}$ under stirring for $30 \mathrm{~min}$. The monomer conversion was obtained using ${ }^{1} \mathrm{H}$ NMR spectroscopy $\left(\mathrm{CDCl}_{3}, 25^{\circ} \mathrm{C}\right)$. After the reaction, the mixture was dissolved in THF, passed through basic alumina to remove catalyst, and precipitated twice in $200 \mathrm{~mL}$ of cold methanol under stirring. The polymer was isolated as a solution after centrifugation at $-4 \stackrel{\circ}{\mathrm{C}}$ and dried by freeze drying to prevent the sulfoxide elimination. $M_{\mathrm{n}, \mathrm{SEC}}$ and $\Theta$ was found to be $7.9 \mathrm{kDa}$ and 1.04 , respectively.

\section{Synthesis of $\mathrm{Ac}-\mathrm{PMA}_{87}$ macroinimer via sulfoxide elimination.}

Into a $100 \mathrm{~mL}$ of Schlenk flask, sPA-PMA $87(1.0 \mathrm{~g})$ and anisole $(50 \mathrm{~mL})$ was added. The reaction mixture was stirred at $110^{\circ} \mathrm{C}$ for $3 \mathrm{~h}$. The solvent was removed by freeze drying. The product was dissolved in THF (5 mL) and precipitated twice in $200 \mathrm{~mL}$ of cold methanol under stirring. The polymer was isolated as a solution after centrifugation at $-4 \stackrel{\circ}{\circ} \mathrm{C}$ and dried by freeze drying to prevent the coupling side reaction of vinyl group. $M_{\mathrm{n}, \mathrm{SEC}}$ and $Ð$ was found to be $8.0 \mathrm{kDa}$ and 1.06 , respectively.

\section{Synthesis of sSt-PMA 70 by SARA ATRP.}

Into a $10 \mathrm{~mL}$ of Schlenk flask, $\mathrm{CuBr}_{2}(4.9 \mathrm{mg}, 22.1 \mu \mathrm{mol}), \mathrm{Cu}^{0}$ wire $(\mathrm{I} \times \mathrm{d}=3 \mathrm{~cm} \times 1 \mathrm{~mm})$ was added. After sealed with rubber septa, the flask was evacuated and backfilled with $\mathrm{N}_{2}$ gas three times. A degassed mixture of MA (4.00 mL, $44.1 \mathrm{mmol})$, sSt (200 mg, $0.441 \mathrm{mmol})$, Me 6 TREN (18.3 mg, $79.4 \mu \mathrm{mol})$, and DMSO (1.96 mL) were added to the flask via $\mathrm{N}_{2}$-purged syringes. The flask was placed in an oil bath at $25 \stackrel{\circ}{\mathrm{C}}$ under stirring for $30 \mathrm{~min}$. The monomer conversion was obtained using ${ }^{1} \mathrm{H}$ NMR spectroscopy $\left(\mathrm{CDCl}_{3}, 25^{\circ} \mathrm{C}\right)$. After the reaction, the mixture was dissolved in THF, passed through basic alumina to remove catalyst, and precipitated twice in $200 \mathrm{~mL}$ of cold methanol under stirring. The polymer was isolated as a solution after centrifugation at $-4 \stackrel{\circ}{\mathrm{C}}$ and dried by freeze drying to prevent the sulfoxide elimination. $M_{\mathrm{n}, \mathrm{SEC}}$ and $\Theta$ was found to be $6.5 \mathrm{kDa}$ and 1.05 , respectively.

\section{Synthesis of St-PMA 70 macroinimer via sulfoxide elimination.}

Into a $100 \mathrm{~mL}$ of Schlenk flask, sSt-PMA70 $(1.0 \mathrm{~g})$ and anisole $(50 \mathrm{~mL})$ was added. The reaction mixture was stirred at $130 \stackrel{\circ}{\circ}$ for $20 \mathrm{~h}$. The solvent was removed by freeze drying. The product was dissolved in THF $(5 \mathrm{~mL})$ and precipitated twice in $200 \mathrm{~mL}$ of cold methanol under stirring. The polymer was isolated as a solution after centrifugation at $-4{ }^{\circ} \mathrm{C}$ and dried by freeze drying to the coupling side reaction of vinyl group. $M_{\mathrm{n}, \mathrm{SEC}}$ and $\oplus$ was found to be $6.7 \mathrm{kDa}$ and 1.10 , respectively. 


\section{Supporting Information}

\section{Hyperbranched PS via one-pot SARA ATRP using sMAc.}

Into a $10 \mathrm{~mL}$ of Schlenk flask, $\mathrm{CuBr}_{2}(1.1 \mathrm{mg} 4.93 \mu \mathrm{mol}), \mathrm{Cu}^{0}$ wire $(\mathrm{I} \times \mathrm{d}=3 \mathrm{~cm} \times 1 \mathrm{~mm})$ was added. After sealed with rubber septa, the flask was evacuated and backfilled with $\mathrm{N}_{2}$ gas three times. A degassed mixture of $\mathrm{S}$ (3.6 mL, $29.6 \mathrm{mmol}), \mathrm{sMAc}(40.0 \mathrm{mg}, 98.7 \mu \mathrm{mol})$, Me6TREN (4.1 mg, $17.8 \mu \mathrm{mol})$, and DMF (1.62 mL) were added to the flask via $\mathrm{N}_{2}$-purged syringes. The flask was placed in an oil bath at $40{ }^{\circ} \mathrm{C}$ under stirring for $4 \mathrm{~h}$. Then, the flask was quickly transferred in an oil bath preheated to $90 \stackrel{\circ}{\circ}$ under stirring for additional $44 \mathrm{~h}$. Samples were withdrawn at timed intervals to measure the monomer conversion and the molecular weight of resulting products using ${ }^{1} \mathrm{H}$ NMR spectroscopy $\left(\mathrm{CDCl}_{3}, 25{ }^{\circ} \mathrm{C}\right)$ and THF eluted SEC with DMF as an internal standard, respectively. After the reaction, the mixture was dissolved in THF, passed through basic alumina to remove catalyst. Absolute molecular weight and intrinsic viscosity were determined by THF eluted SEC with triple detector.

\section{Solvolysis of hyperbranched polymer.}

The hyperbranched polymer $(50 \mathrm{mg})$ was dissolved in a mixture of dioxane $(6 \mathrm{~mL})$ and 1-octanol $(6 \mathrm{~mL})$. Concentrated sulfuric acid (4 drops) was added, and the solution was refluxed at $130{ }^{\circ} \mathrm{C}$ for 3 days. ${ }^{2}$ The product was purified using a dialysis membrane bag $(\mathrm{MWCO}=1 \mathrm{kDa})$ against acetone for $48 \mathrm{~h}$. The solvent was evaporated under vacuum, and the remaining residue was dissolved in $\mathrm{CH}_{2} \mathrm{Cl}_{2}(15 \mathrm{~mL})$. After extracting with water $(5 \mathrm{~mL})$, the organic layer was isolated and dried in vacuo at room temperature. The resulting polymer was characterized by SEC. 
NMR spectra and SEC chromatograms

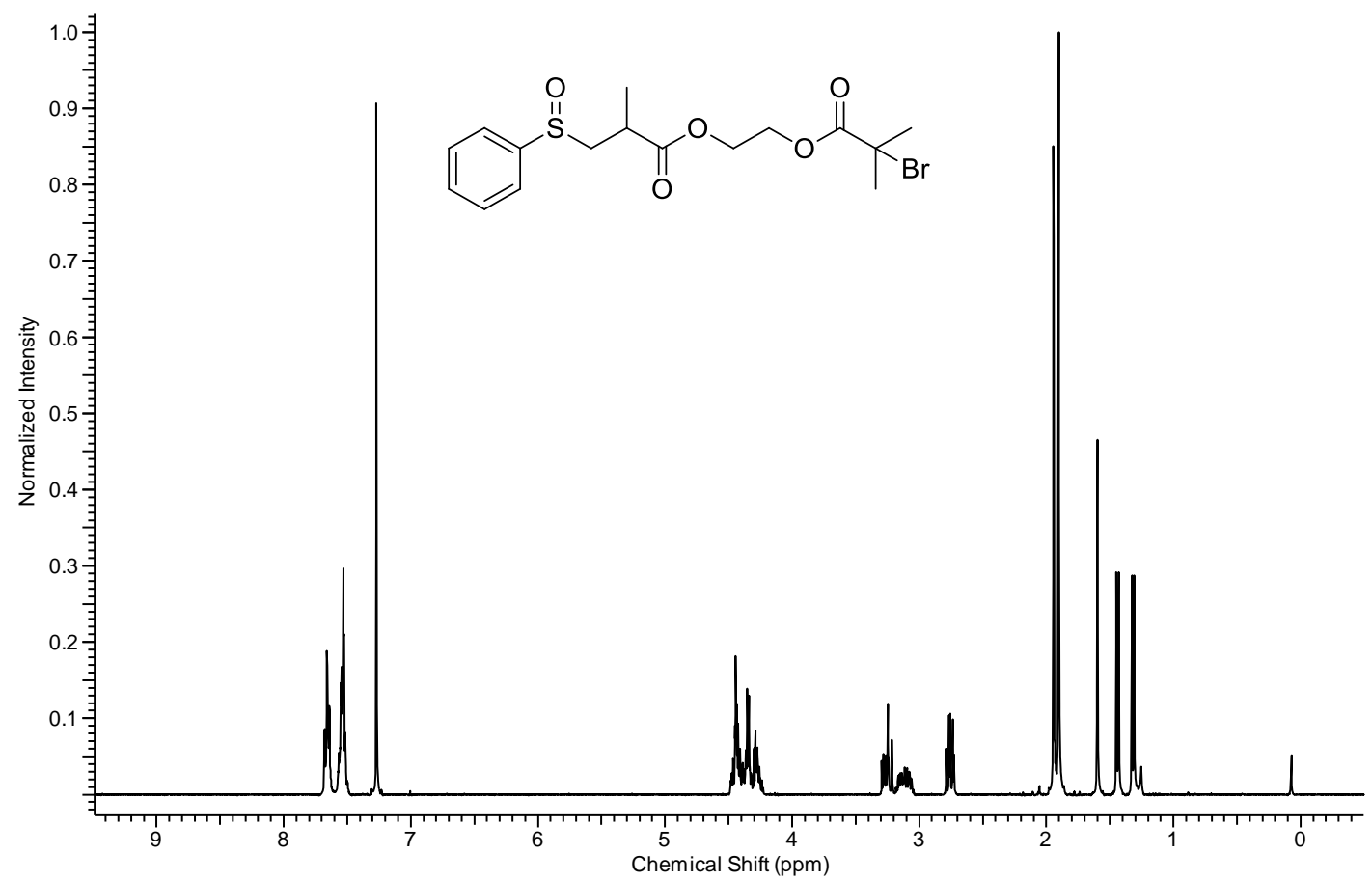

Figure S1. ${ }^{1} \mathrm{H}$ NMR spectrum $\left(\mathrm{CDCl}_{3}, 25^{\circ} \mathrm{C}\right)$ of sMAc.

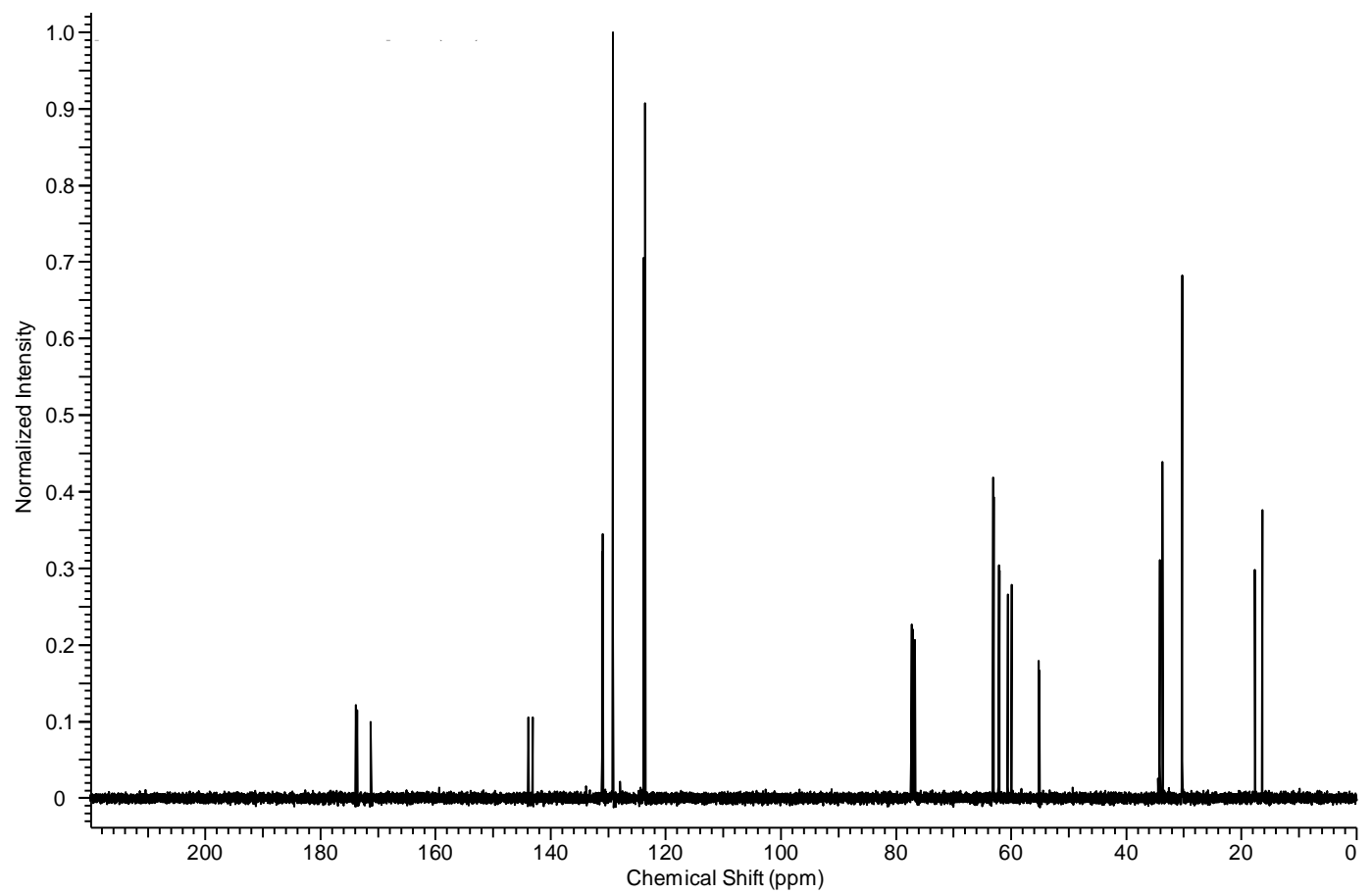

Figure S2. ${ }^{13} \mathrm{C}$ NMR spectrum $\left(\mathrm{CDCl}_{3}, 25^{\circ} \mathrm{C}\right)$ of sMAc. 


\section{Supporting Information}

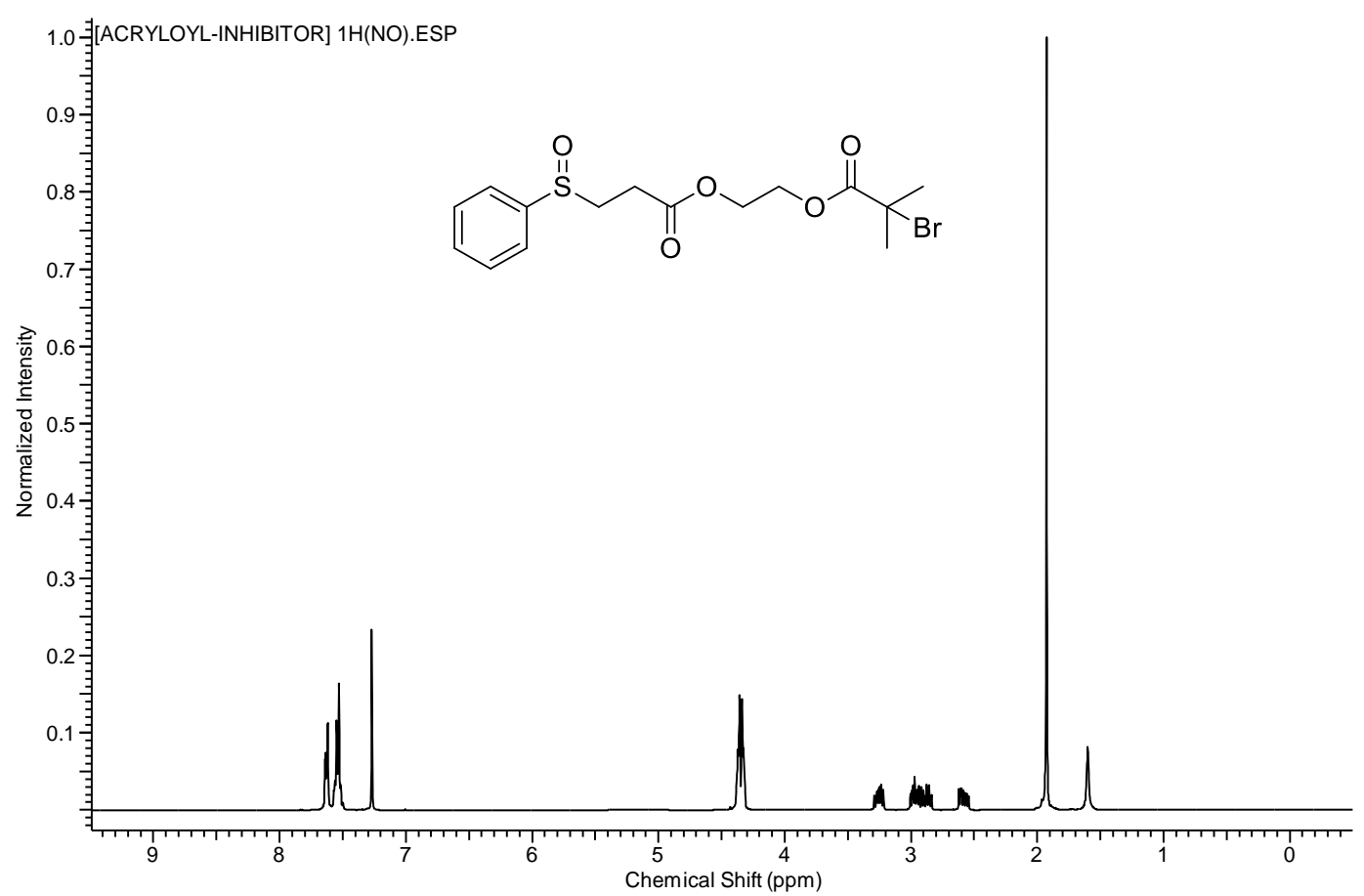

Figure S3. ${ }^{1} \mathrm{H}$ NMR spectrum $\left(\mathrm{CDCl}_{3}, 25 \stackrel{\circ}{\circ}\right)$ of sAc.

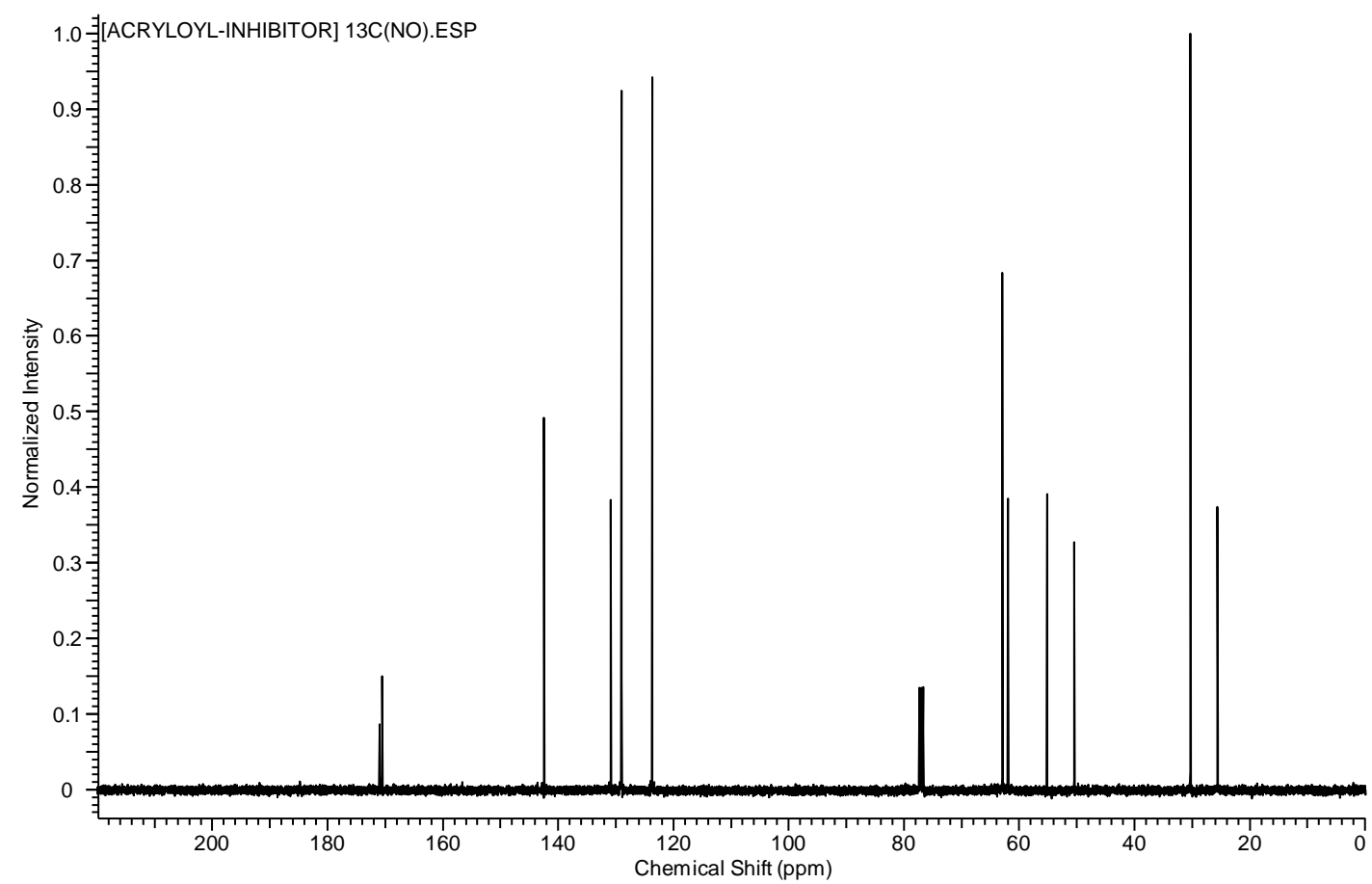

Figure S4. ${ }^{13} \mathrm{C}$ NMR spectrum $\left(\mathrm{CDCl}_{3}, 25^{\circ} \mathrm{C}\right)$ of sAc. 


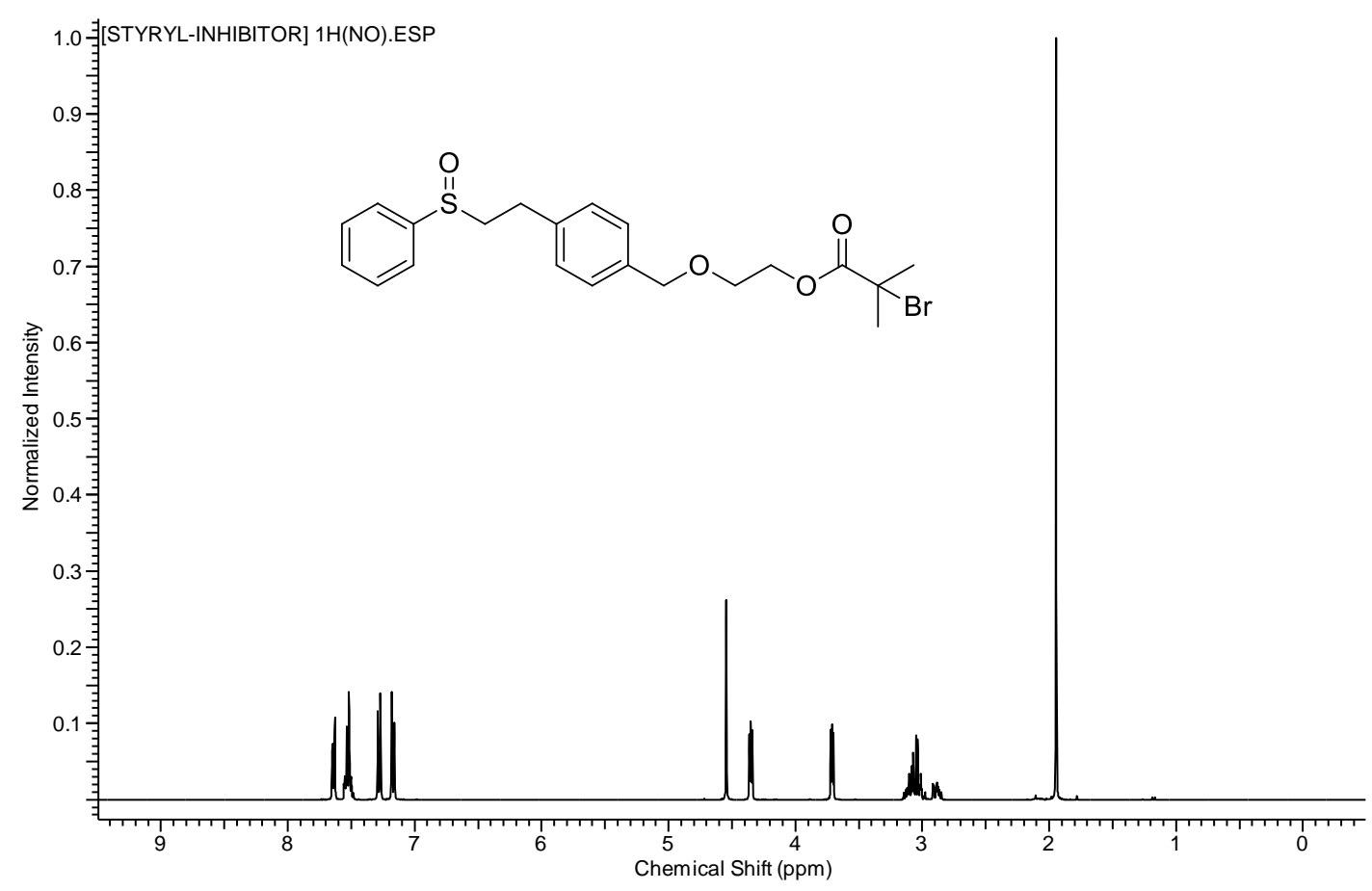

Figure S5. ${ }^{1} \mathrm{H}$ NMR spectrum $\left(\mathrm{CDCl}_{3}, 25 \stackrel{\circ}{\circ}\right)$ of sSt.

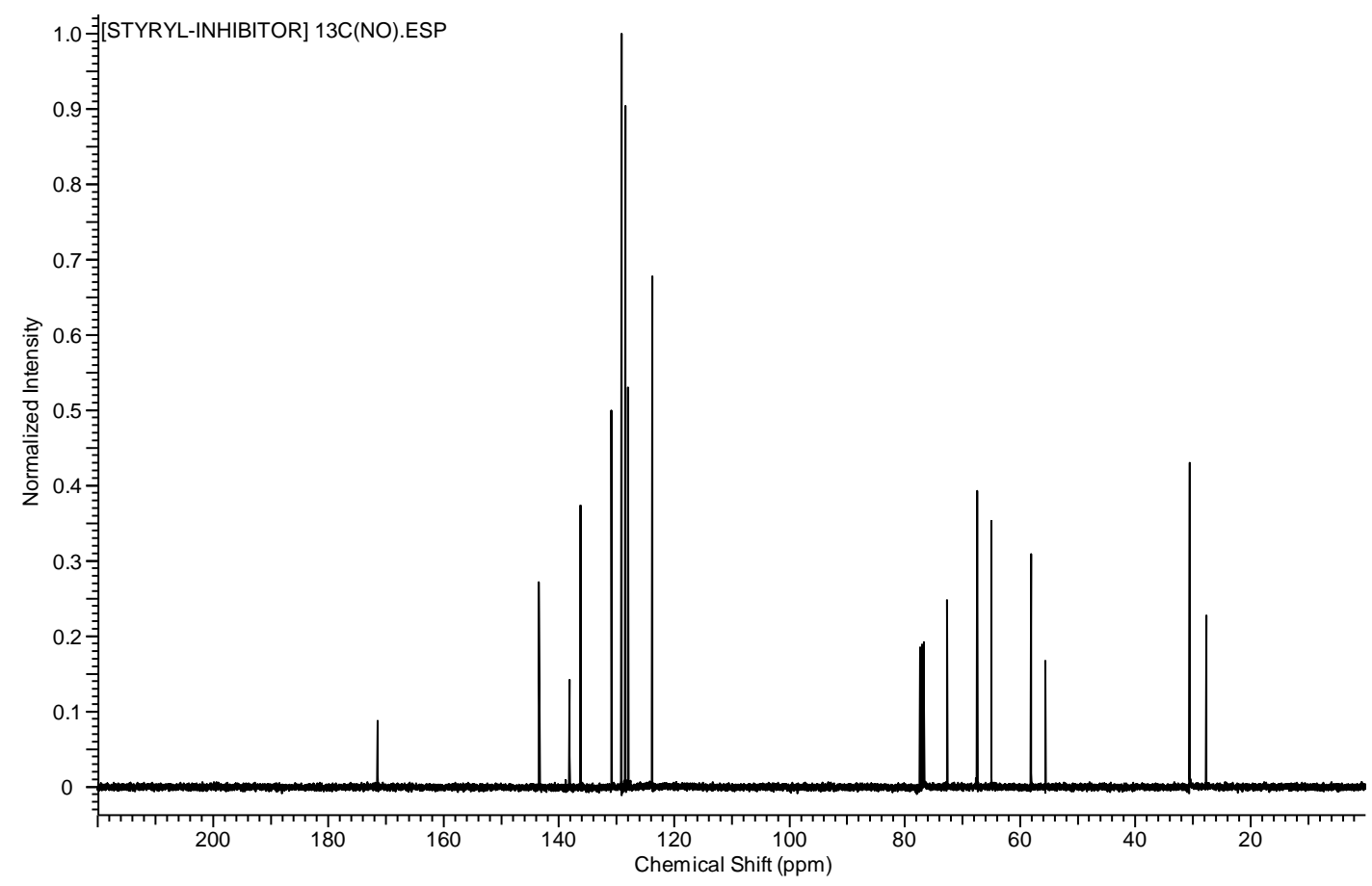

Figure S6. ${ }^{13} \mathrm{C}$ NMR spectrum $\left(\mathrm{CDCl}_{3}, 25^{\circ} \mathrm{C}\right)$ of sSt. 


\section{Supporting Information}

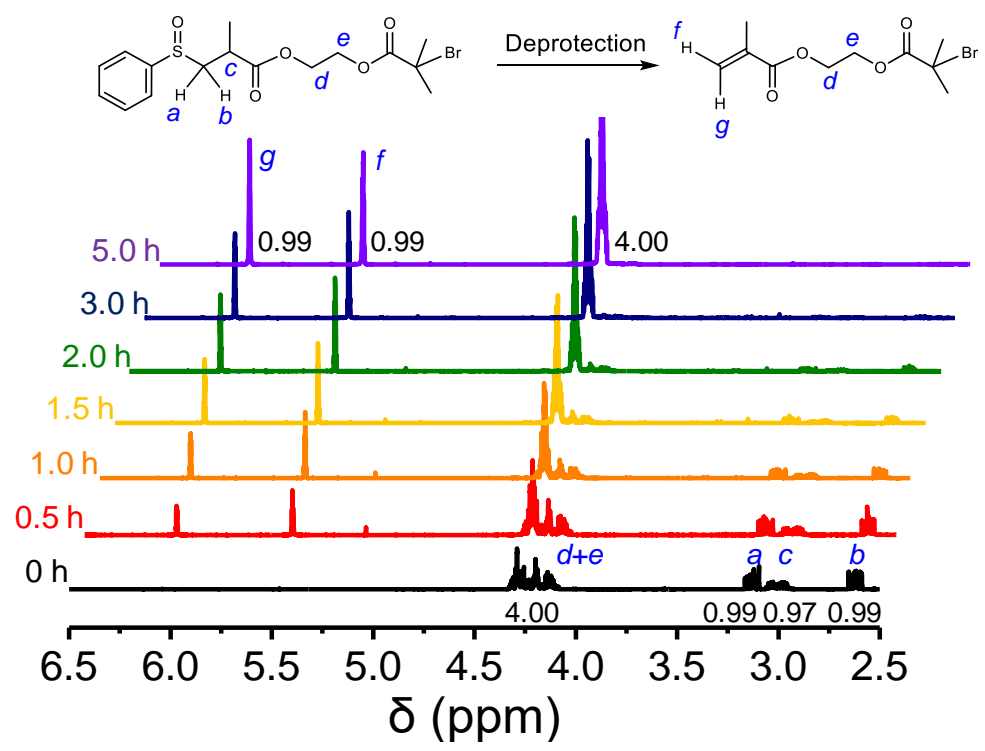

Figure S7. Stacked ${ }^{1} \mathrm{H}$ NMR spectra $\left(\mathrm{CDCl}_{3}, 25^{\circ} \mathrm{C}\right)$ of transformation of sMAc into MAc inimer.

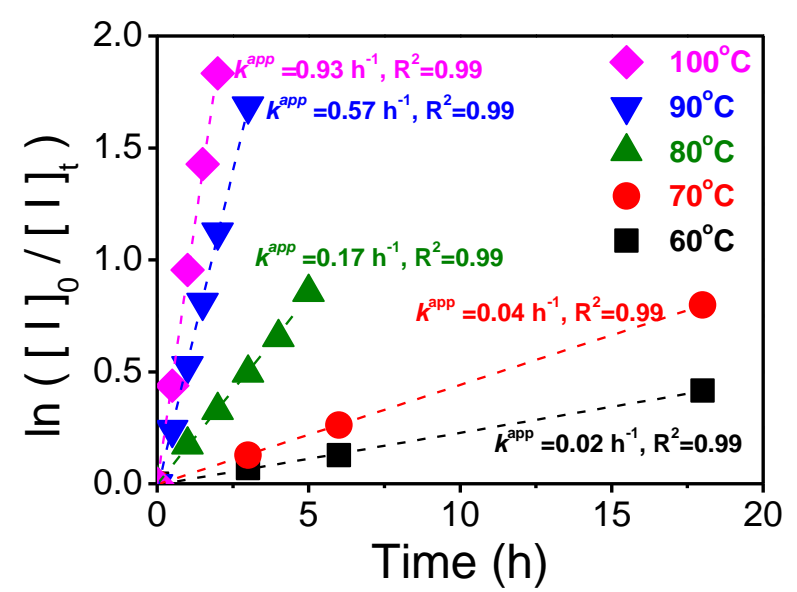

Figure S8. sMAc consumption plots of $\ln \left(\left[[]_{0} /[]_{\mathrm{t}}\right)\right.$ versus time during the sulfoxide elimination reaction at indicated temperatures.

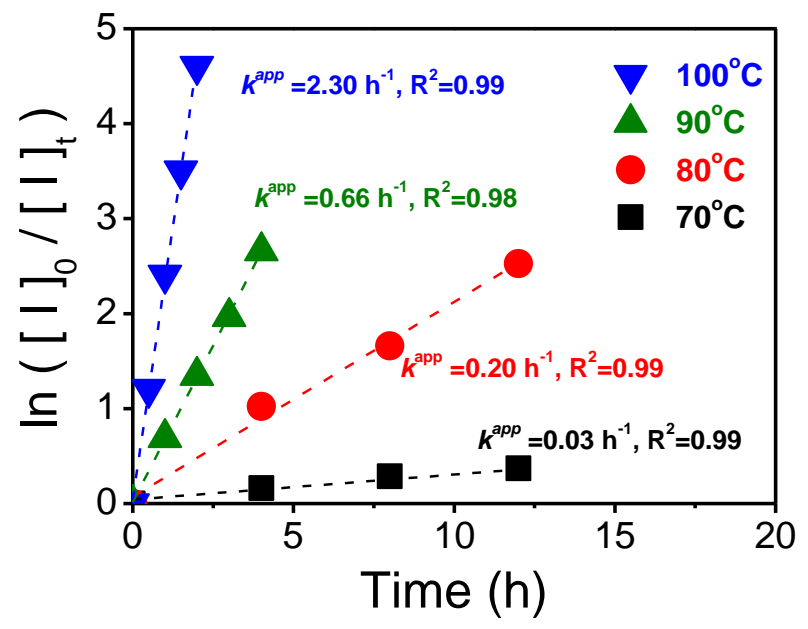

Figure S9. sAc consumption plots of $\ln \left(\left[[]_{0} /[]_{t}\right)\right.$ versus time during the sulfoxide elimination reaction at indicated temperatures. 


\section{Supporting Information}

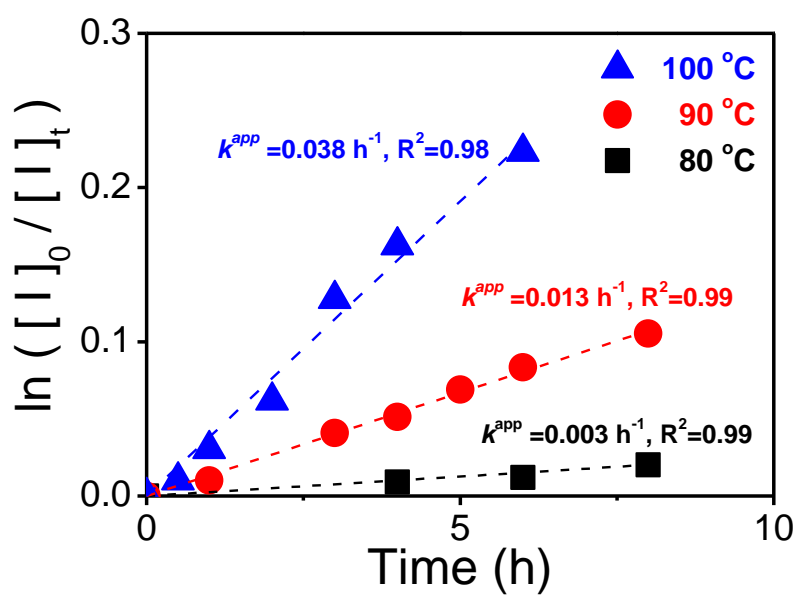

Figure S10. sSt consumption plots of $\ln \left(\left[[]_{0} /[]_{t}\right)\right.$ versus time during the sulfoxide elimination reaction at indicated temperatures.

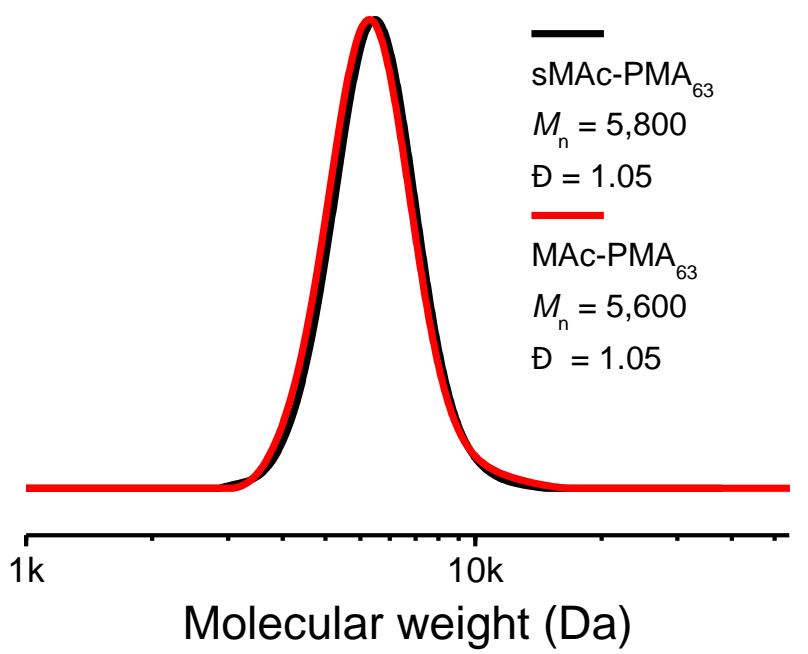

Figure S11. Molecular weight comparison between sMAc-PMA63 (一, black line) and MAc-PMA63 (一, red line), obtained using polystyrene standards calibrated SEC. 

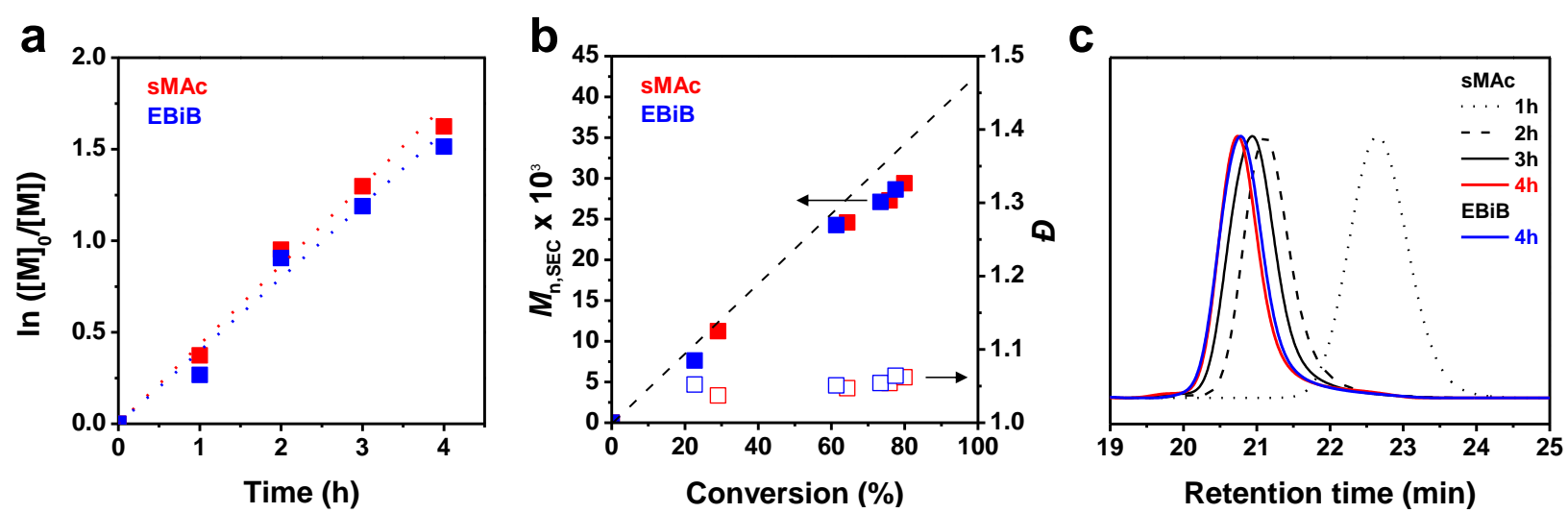

Figure S12. Comparison of SARA ATRP of MA using SMAc and EBiB as the initiator. (a) Semi-logarithmic plots of the monomer concentration vs. time. (b) Plots of number average molecular weights $\left(M_{\mathrm{n}, \mathrm{SEC}}\right)$ and dispersity $(\nexists)$ vs. conversion. (c) Molecular weight evolution measured using SEC. Reaction conditions: []$_{0}:[\text { monomer }]_{0}:\left[\mathrm{CuBr}_{2}\right]_{0}$ : $\left[\mathrm{Me}_{6} \mathrm{TREN}_{0}=1: 500: 0.05: 0.18 ;[\mathrm{MA}]_{0}=7.4 \mathrm{M}\right.$ in DMSO; $25^{\circ} \mathrm{C} ; \mathrm{Cu}^{0}$ wire $(\mathrm{I} \times \mathrm{d}=3 \mathrm{~cm} \times 1 \mathrm{~mm})$ under nitrogen unless otherwise stated. 


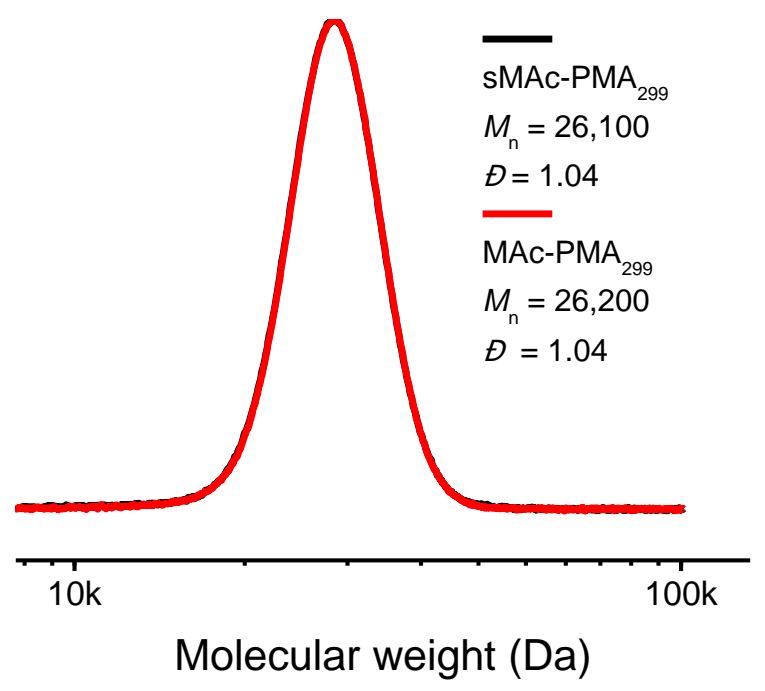

Figure S13. Molecular weight comparison between sMAc-PMA299 (一, black line) and MAc-PMA 299 (一, red line), obtained using polystyrene standards calibrated SEC.

a

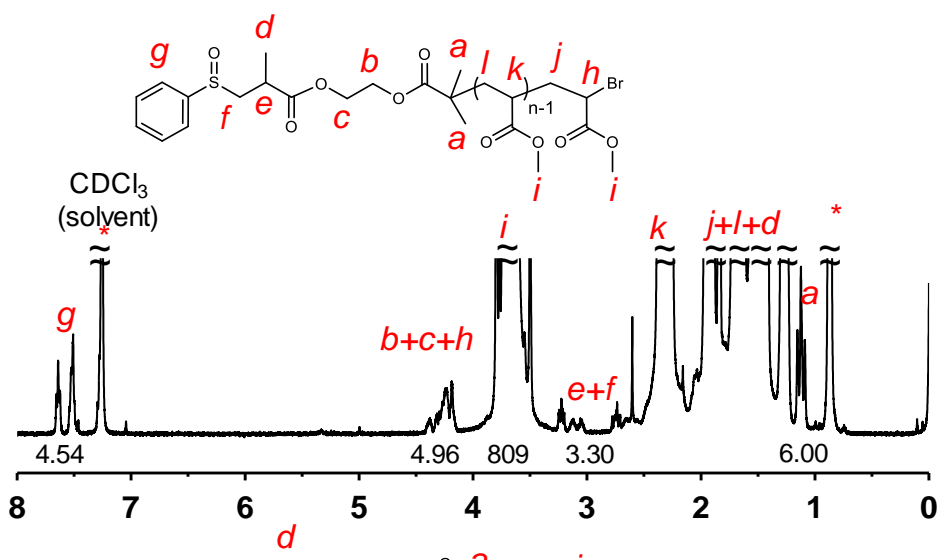

b

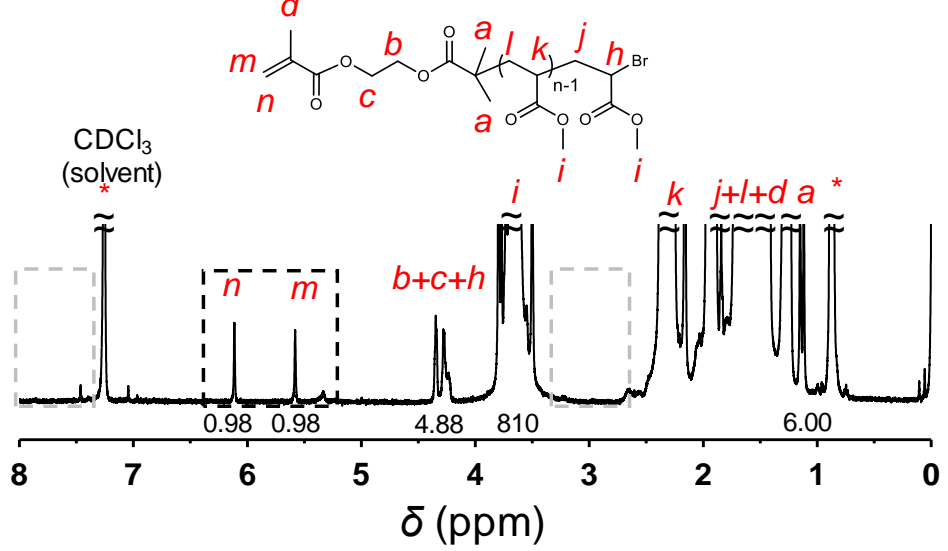

Figure S14. Molecular structure comparison between sMAc-PMA 299 and $M A c-P M A_{299}$ using ${ }^{1} \mathrm{H}$ NMR spectroscopy $\left(\mathrm{CDCl}_{3}, 25^{\circ} \mathrm{C}\right)$. (a) sMAc-PMA 299 and (b) MAc-PMA 299 . 


\section{Supporting Information}

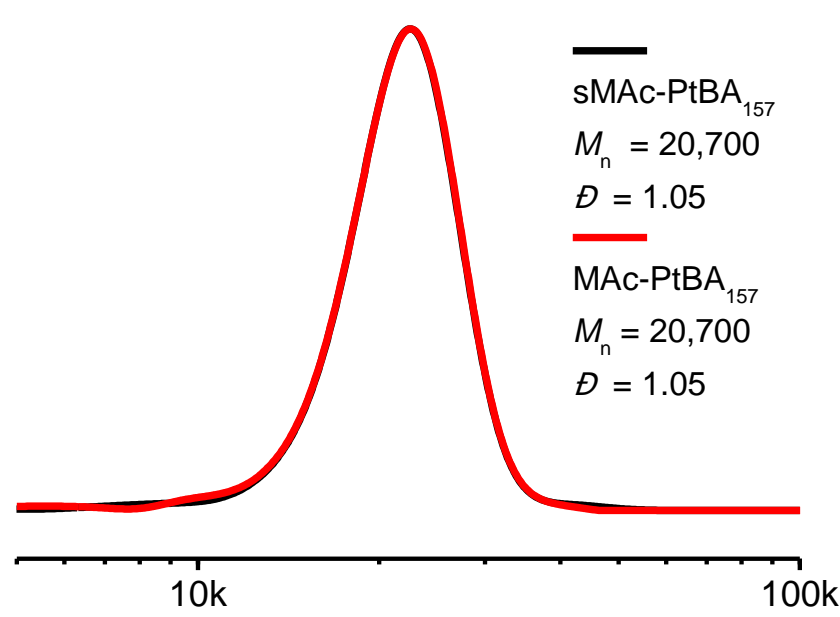

Molecular weight (Da)

Figure S15. Molecular weight comparison between sMAc-PtBA ${ }_{157}(-$, black line) and MAc-PtBA 157 (一, red line), obtained using polystyrene standards calibrated SEC.

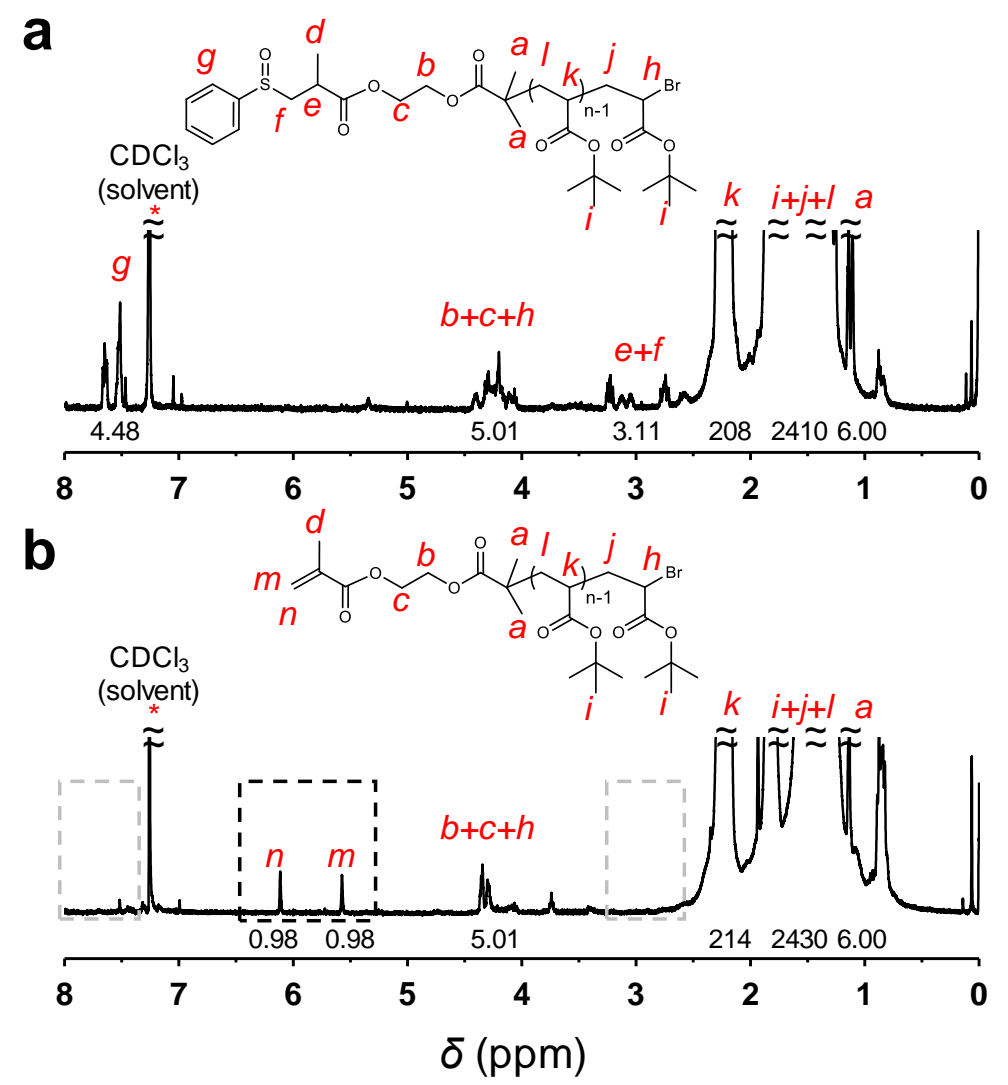

Figure S16. Molecular structure comparison between sMAc-PtBA 157 and MAc-PtBA ${ }_{157}$ using ${ }^{1} \mathrm{H}$ NMR spectroscopy $\left(\mathrm{CDCl}_{3}, 25^{\circ} \mathrm{C}\right)$. (a) sMAc-PtBA 157 and (b) MAc-PtBA 157. 


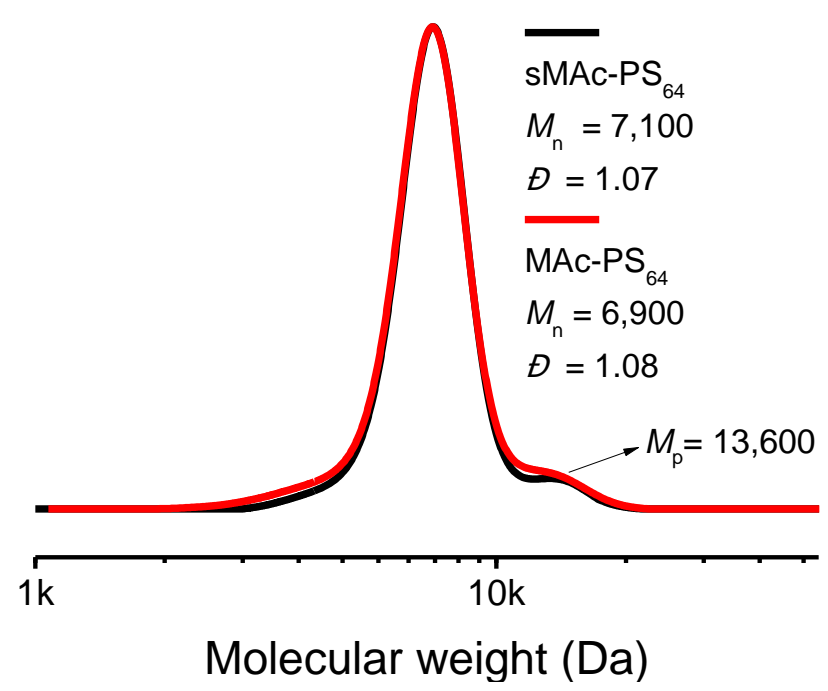

Figure S17. Molecular weight comparison between $\operatorname{sMAc}-P S_{64}(-$, black line) and MAc-PS 64 (-, red line), obtained using polystyrene standards calibrated SEC.

a

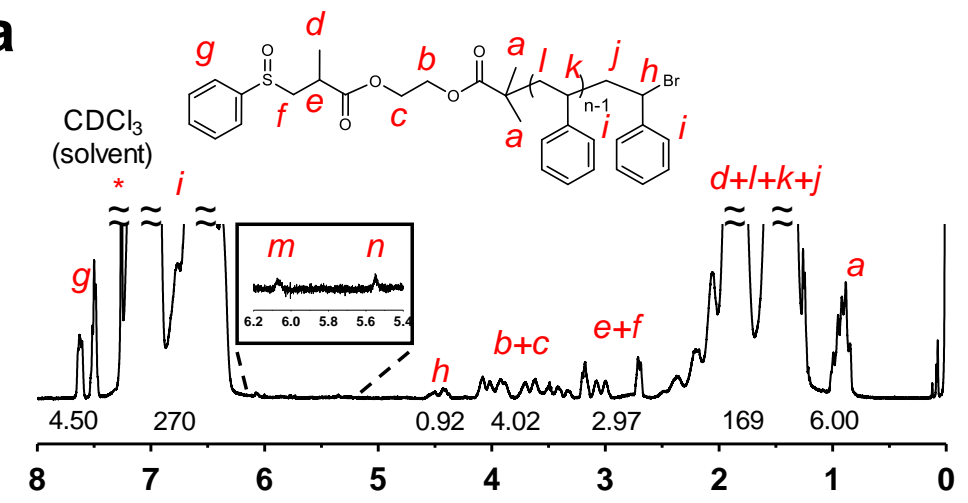

b

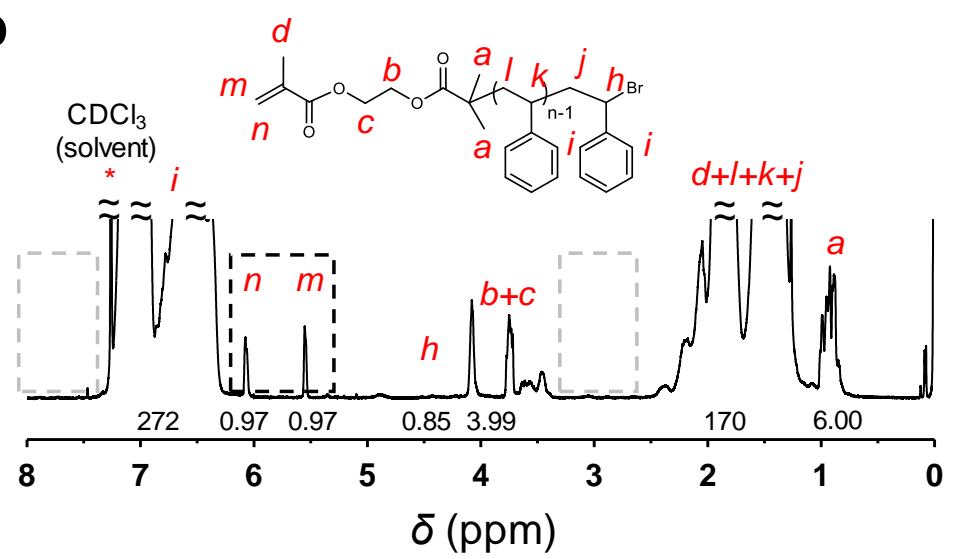

Figure S18. Molecular structure comparison between sMAc-PS 64 and MAc-PS 64 using ${ }^{1} \mathrm{H}$ NMR spectroscopy $\left(\mathrm{CDCl}_{3}, 25^{\circ} \mathrm{C}\right) .(\mathrm{a}) \mathrm{SMAc}^{-P S_{64}}$ and (b) MAc-PS 64. 


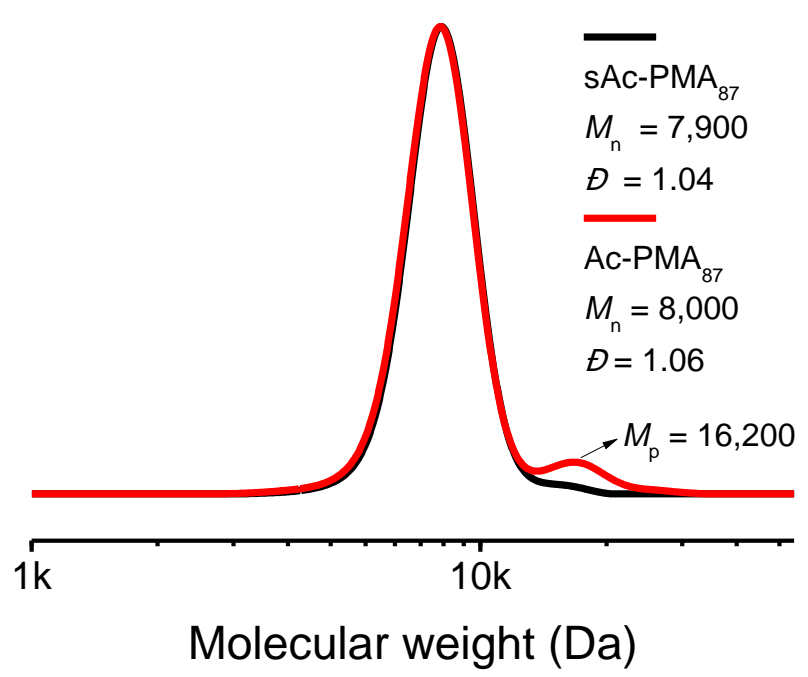

Figure S19. Molecular weight comparison between $\operatorname{sAc}^{-P M A} A_{87}\left(-\right.$, black line) and $\operatorname{Ac}_{-}-\mathrm{PMA}_{87}$ (一, red line), obtained using polystyrene standards calibrated SEC.

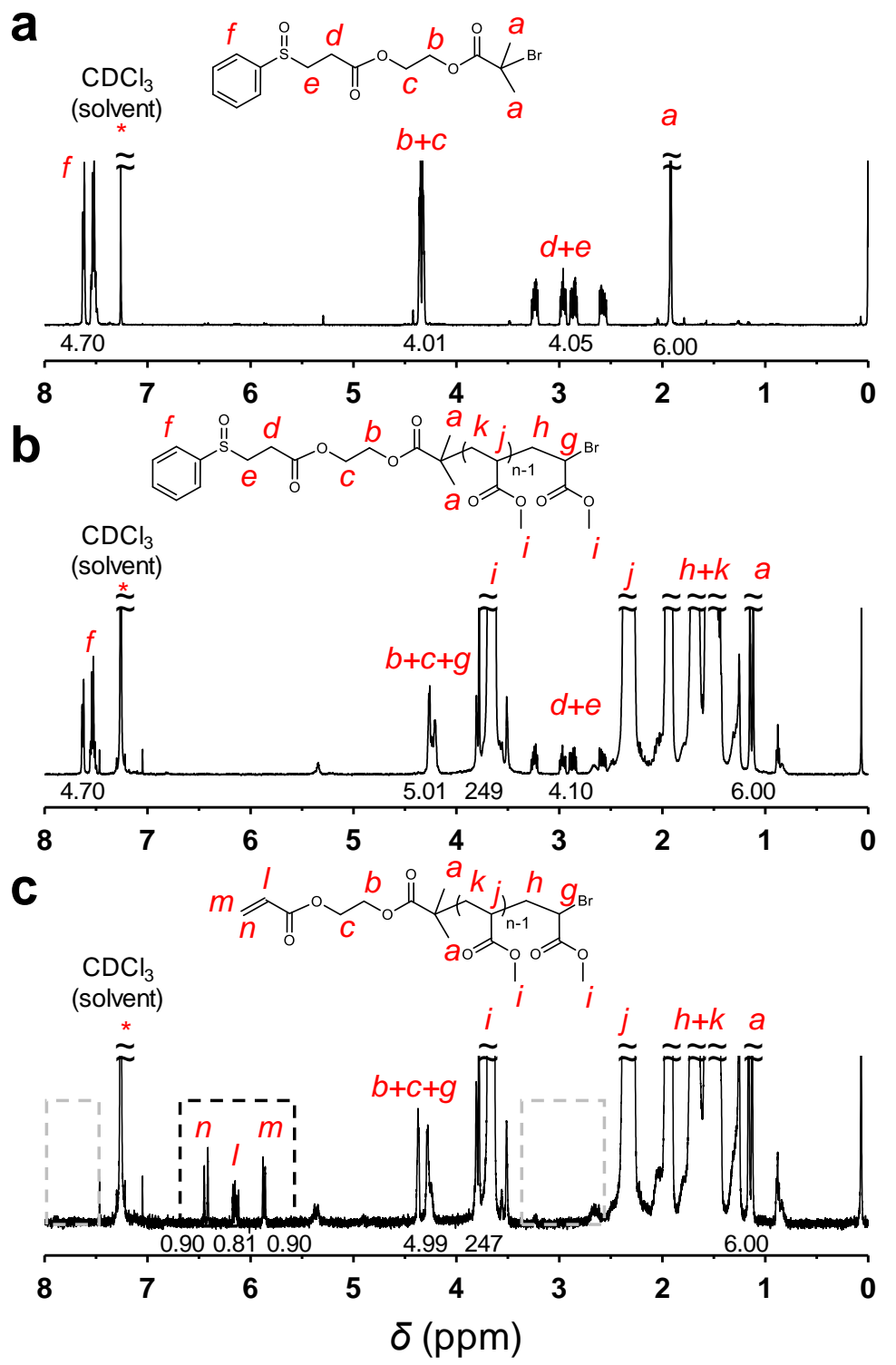

Figure S20. Molecular structure comparison between sAc, sAc-PMA87, and Ac-PMA87 using ${ }^{1} \mathrm{H}$ NMR spectroscopy $\left(\mathrm{CDCl}_{3}, 25 \stackrel{\circ}{\circ}\right.$ ). (a) sAc, (b) sAc-PMA87, and (c) Ac-PMA87. 


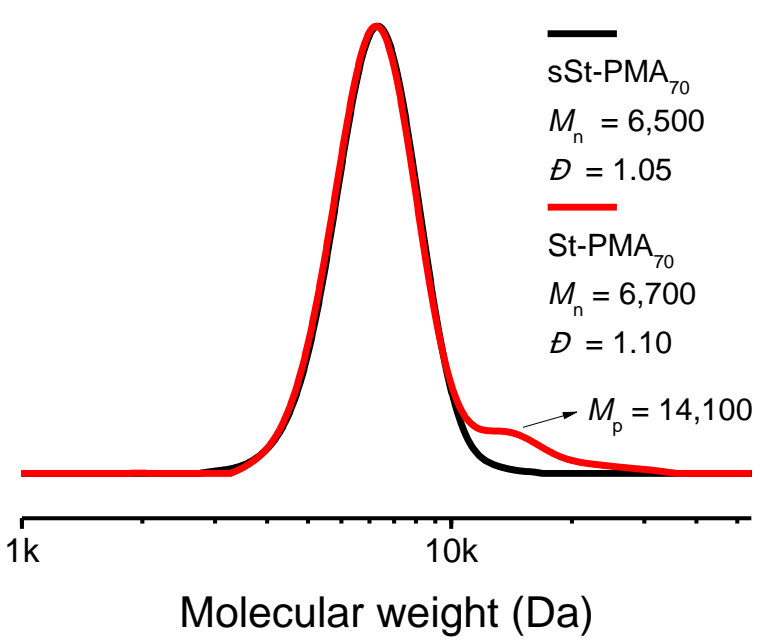

Figure S21. Molecular weight comparison between sSt-PMA70 (—, black line) and St-PMA70 (一, red line), obtained using polystyrene standards calibrated SEC.
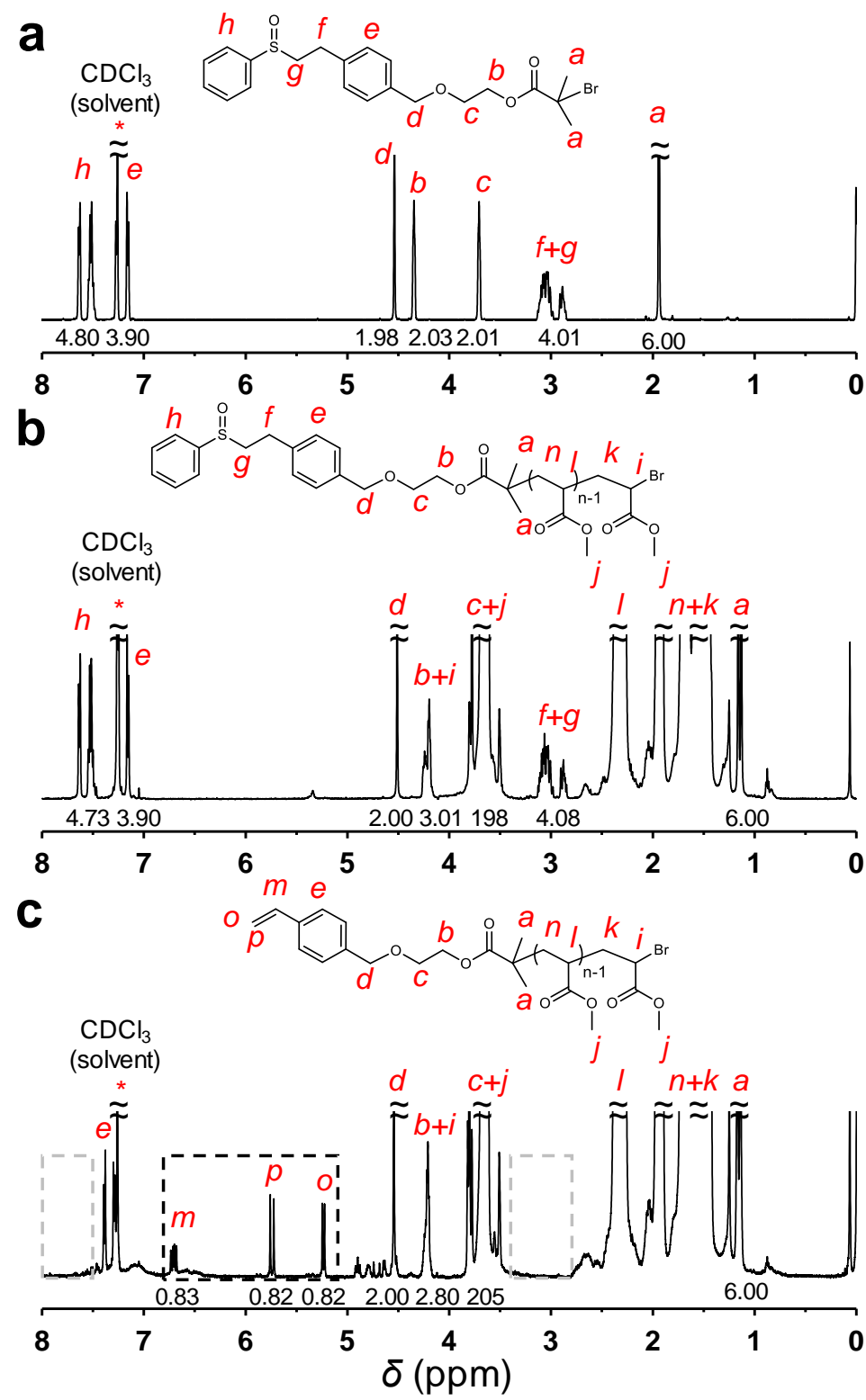

Figure S22. Molecular structure comparison between sSt, sSt-PMA 70 , and St-PMA 70 using ${ }^{1} \mathrm{H}$ NMR spectroscopy $\left(\mathrm{CDCl}_{3}, 25 \stackrel{\circ}{\circ}\right.$ ). (a) sSt, (b) sSt-PMA70, and (c) St-PMA70. 


\section{Supporting Information}

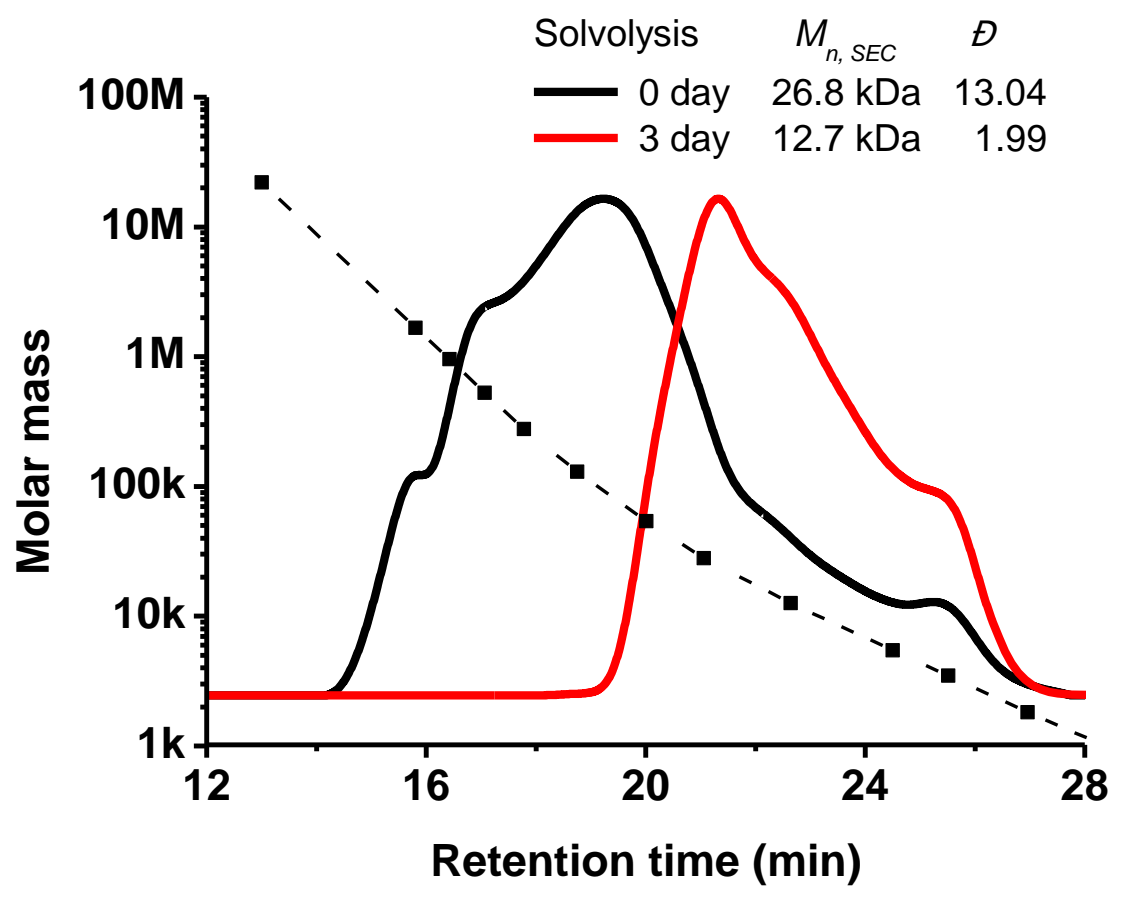

Figure S23. SEC chromatogram comparison of the hyperbranched polymers (-, black line) and the polymers after solvolysis (-, red line). 


\section{References}

1. Altuntaş, E.; Krieg, A.; Baumgaertel, A.; Crecelius, A. C.; Schubert, U. S. ESI, APCI, and MALDI tandem mass spectrometry of poly(methyl acrylate)s: A comparison study for the structural characterization of polymers synthesized via CRP techniques and the software application to analyze MS/MS data. J. Polym. Sci., Part A: Polym. Chem. 2013, 51, 1595-1605 DOI: 10.1002/pola.26529.

2. Liang, H.; Morgan, B. J.; Xie, G.; Martinez, M. R.; Zhulina, E. B.; Matyjaszewski, K.; Sheiko, S. S.; Dobrynin, A. V. Universality of the Entanglement Plateau Modulus of Comb and Bottlebrush Polymer Melts. Macromolecules 2018, 51, 10028-10039 DOI: 10.1021/acs.macromol.8b01761. 